\title{
Calcium-Regulation of Mitochondrial Respiration Maintains ATP Homeostasis and Requires ARALAR/AGC1-Malate Aspartate Shuttle in Intact Cortical Neurons
}

\author{
Irene Llorente-Folch, ${ }^{1,2 \star}$ Carlos B. Rueda, ${ }^{1,2 \star}$ Ignacio Amigo, ${ }^{1,2}$ Araceli del Arco, ${ }^{2,3}$ Takeyori Saheki, ${ }^{4}$ Beatriz Pardo, ${ }^{1,2}$ \\ and Jorgina Satrústegui ${ }^{1,2}$ \\ ${ }^{1}$ Departament of Molecular Biology, Centre for Molecular Biology Severo Ochoa UAM-CSIC, Autonomous University of Madrid, Madrid, Spain, ${ }^{2}$ CIBER or \\ Rare Diseases (CIBERER), ${ }^{3}$ Area of Biochemistry, Regional Centre for Biochemical Research (CRIB), Faculty of Environmental Science and Biochemistry, \\ University of Castilla-La Mancha, Toledo Spain, and ${ }^{4}$ Institute of Resource Development and Analysis, Kumamoto University, Honjo, Kumamoto, Japan
}

Neuronal respiration is controlled by ATP demand and $\mathrm{Ca}^{2+}$ but the roles played by each are unknown, as any $\mathrm{Ca}^{2+}$ signal also impacts on ATP demand. $\mathrm{Ca}^{2+}$ can control mitochondrial function through $\mathrm{Ca}^{2+}$-regulated mitochondrial carriers, the aspartate-glutamate and ATP-Mg/Pi carriers, ARALAR/AGC1 and SCaMC-3, respectively, or in the matrix after $\mathrm{Ca}^{2+}$ transport through the $\mathrm{Ca}^{2+}$ uniporter. We have studied the role of $\mathrm{Ca}^{2+}$ signaling in the regulation of mitochondrial respiration in intact mouse cortical neurons in basal conditions and in response to increased workload caused by increases in $\left[\mathrm{Na}^{+}\right]_{\text {cyt }}$ (veratridine, high- $\mathrm{K}^{+}$depolarization) and/or $\left[\mathrm{Ca}^{2+}\right]_{\mathrm{cyt}}(\mathrm{carba}$ chol). Respiration in nonstimulated neurons on 2.5-5 mm glucose depends on ARALAR-malate aspartate shuttle (MAS), with a $46 \%$ drop in aralar KO neurons. All stimulation conditions induced increased OCR (oxygen consumption rate) in the presence of $\mathrm{Ca}^{2+}$, which was prevented by BAPTA-AM loading (to preserve the workload), or in $\mathrm{Ca}^{2+}$-free medium (which also lowers cell workload). SCaMC-3 limits respiration only in response to high workloads and robust $\mathrm{Ca}^{2+}$ signals. In every condition tested $\mathrm{Ca}^{2+}$ activation of ARALAR-MAS was required to fully stimulate coupled respiration by promoting pyruvate entry into mitochondria. In aralar K0 neurons, respiration was stimulated by veratridine, but not by $\mathrm{KCl}$ or carbachol, indicating that the $\mathrm{Ca}^{2+}$ uniporter pathway played a role in the first, but not in the second condition, even though $\mathrm{KCl}$ caused an increase in $\left[\mathrm{Ca}^{2+}\right]_{\text {mit }}$. The results suggest a requirement for ARALAR-MAS in priming pyruvate entry in mitochondria as a step needed to activate respiration by $\mathrm{Ca}^{2+}$ in response to moderate workloads.

\section{Introduction}

Oxygen consumption is controlled by the mitochondrial proton electrochemical gradient $\left(\Delta \mu \mathrm{H}^{+}\right.$; Mitchell and Moyle, 1969). In most cell types, $\Delta \mu \mathrm{H}^{+}$is mainly used in ATP synthesis. Increases in cell workload will consume ATP and lead to increased ATP production in mitochondria, through the utilization of $\Delta \mu \mathrm{H}^{+}$. This in turn, will stimulate respiration. However, even at high workloads, a rapid formation of ATP through phosphocreatine

\footnotetext{
Received March 1, 2013; revised June 11, 2013; accepted June 13, 2013.

Author contributions:I.L.-F., C.B.R., A.d.A., B.P., and J.S. designed research;I.L.-F. and C.B.R. performed research; T.S. contributed unpublished reagents/analytic tools; I.L.-F., C.B.R., and I.A. analyzed data; I.L.-F., C.B.R., and J.S. wrote the paper.

This work was supported by the Ministerio de Economía Grant BFU2011-30456, by CIBERER (an initiative of the ISCIII), by the Comunidad de Madrid Grant S2010/BMD-2402 MITOLAB-CM (to J.S.), by ISCIII Grant PI080610 (to A.d.A.), and by an institutional grant from the Fundación Ramon Areces to the Centro de Biología Molecular Severo Ochoa. C.B.R is a recipient of a FPU fellowship from the Ministerio de Educación y Ciencia. We thank Dr. Hiromi Imamura, Kyoto University for kindly providing the G0-ATeam plasmids. We thank Isabel Manso, Alejandro Arandilla, and Bárbara Sesé for technical support, José Belio for his help in preparing the figures, and María Angeles Muñoz, from the Unit of Optical and Confocal Microscopy, for her inestimable support.

The authors declare no competing financial interests.

*I.L.-F. and C.B.R. contributed equally to this work.

Correspondence should be addressed to Dr. Jorgina Satrústegui, Universidad Autonoma de Madrid, Centro de Biologia Molecular Severo, Nicolas Cabrera 1, Madrid, 28049, Spain. E-mail: jsatrustegui@cbm.uam.es.

DOI:10.1523/JNEUROSCI.0929-13.2013

Copyright $\odot 2013$ the authors $\quad 0270-6474 / 13 / 3313957-15 \$ 15.00 / 0$
}

and the creatine kinase reaction maintains cell ATP at almost constant levels (Cerdan et al., 1990).

In excitable cells, $\mathrm{Ca}^{2+}$ regulates cell function both by activation of ATP consumption (contraction, ion transport) and by activating ATP production through stimulation of oxidative phosphorylation. $\mathrm{Ca}^{2+}$ regulation of oxidative phosphorylation is thought to involve $\mathrm{Ca}^{2+}$ entry in mitochondria through the $\mathrm{Ca}^{2+}$ uniporter (MCU) and activation of three matrix dehydrogenases and complex V (McCormack et al., 1990; Glancy and Balaban, 2012). It may also occur through $\mathrm{Ca}^{2+}$ activation of mitochondrial metabolite transporters, by $\mathrm{Ca}^{2+}$ acting on the external side of the inner mitochondrial membrane. There are two types of such transporters, the aspartate-glutamate carriers (AGCs) and the ATP-Mg/Pi transporters (del Arco and Satrústegui, 1998; Palmieri et al., 2001; Satrústegui et al., 2007; Traba et al., 2012; Amigo et al., 2013).

ARALAR/AGC1 is present in brain and it is a component of the malate aspartate NADH shuttle (MAS). Activation by extramitochondrial $\mathrm{Ca}^{2+}$ of ARALAR-MAS results in an increase in NADH production in neuronal mitochondria (Pardo et al., 2006) and Gellerich et al. $(2009,2012,2013)$ have proposed that $\mathrm{Ca}^{2+}$-activation of ARALAR functions as a "gas pedal" to increase pyruvate formation.

SCaMC-3 is the main mitochondrial ATP-Mg/Pi carrier present in brain and liver (del Arco and Satrústegui, 2004; 
Fiermonte et al., 2004; Amigo et al., 2013). Although not involved in oxidative phosphorylation, which requires adenine nucleotide exchange by the ADP/ATP carriers, adenine nucleotide accumulation in rat liver mitochondria through the ATP- $\mathrm{Mg} / \mathrm{Pi}$ carrier results in a progressive increase in state 3 respiration (ADP-stimulated respiration; Asimakis and Aprille, 1980; Aprille et al., 1987; Amigo et al., 2013), perhaps by increasing the driving force of the ATP-synthase (Balaban et al., 2009; Glancy and Balaban, 2012).

The control of respiration by $\mathrm{Ca}^{2+}$ in intact neurons is still largely unknown. Hayakawa et al. (2005) described rapid $\mathrm{Ca}^{2+}$ dependent changes in oxygen consumption in response to high $\mathrm{KCl}$ in cultured Purkinje neurons, but Mathiesen et al. (2011) found no evidence for a role of cytosolic $\mathrm{Ca}^{2+}$ in activitydependent rises in cerebral metabolic rate of oxygen $\left(\mathrm{CMRO}_{2}\right)$ in cerebellar Purkinje neurons in the intact brain. Bak et al. (2012) described a Ca ${ }^{2+}$-induced increased in flux through the tricarboxylic acid cycle in cerebellar neurons using glucose as substrate. A confounding variable in these and other studies relates to the coincidence of the $\mathrm{Ca}^{2+}$-mechanism with the classical mechanism activating mitochondrial respiration, i.e., ATP demand. Indeed, any $\mathrm{Ca}^{2+}$ signal involves ATP consumption to recover prestimulation values, and the role of $\mathrm{Ca}^{2+}$ versus ADPstimulation of respiration needs to be established.

The purpose of this work was to study the role of $\mathrm{Ca}^{2+}$ in the control of respiration under basal conditions and in response to an increase in workload in neuronal cultures. Particularly, to evaluate the contribution of the ARALAR-MAS and SCaMC-3 pathways of $\mathrm{Ca}^{2+}$ signaling to mitochondria with respect to that of MCU.

\section{Materials and Methods}

Animals. Male SVJ129 × C57BL/6 mice carrying a deficiency for aralar expression ( aralar $^{-1-}$, aralar $^{+/-}$, and aralar $^{+/+}$) obtained from Lexicon Pharmaceuticals were used (Jalil et al., 2005). Mice deficient in SCaMC-3 were generated by Lexicon Pharmaceuticals with a mixed C57BL6/Sv129 genetic background (Amigo et al., 2013). Animals are born in Mendelian proportions and show no evident phenotypic traits. The mice were housed in a humidity- and temperature-controlled room on a $12 \mathrm{~h} \mathrm{light/dark}$ cycle, receiving water and food ad libitum. All the experimental protocols performed in this study were performed in accordance with procedures approved in the Directive 86/609/EEC of the European Union and with approval of the local Ethics Committee of the Universidad Autónoma de Madrid. All efforts were made to minimize animal suffering.

Genotypes. Genotypes were determined, as previously described for aralar (Pardo et al., 2006) and SCaMC-3 (Amigo et al., 2013), by PCR using genomic DNA obtained from tail or embryonic tissue samples (Nucleospin tissue kit, Macherey-Nagel). PCR mixtures were preincubated at $94^{\circ} \mathrm{C}$ for $5 \mathrm{~min}$, followed by 35 cycles of DNA amplification at $94^{\circ} \mathrm{C}$ for $60 \mathrm{~s}, 58^{\circ} \mathrm{C}$ for $60 \mathrm{~s}$, and $72^{\circ} \mathrm{C}$ for $60 \mathrm{~s}$; the process was finished with incubation at $72^{\circ} \mathrm{C}$ for $5 \mathrm{~min}$. DNA fragments were separated by electrophoresis on a $1.5 \%$ agarose gel.

Neuronal culture. Cortical neuronal cultures were prepared from E15E16 mouse embryos as described earlier (Ramos et al., 2003; Pardo et al., 2006). Embryos were obtained from crosses between C57BL6/SV129 aralar $^{+/-}$mice, C57BL6/SV129 SCaMC-3 ${ }^{+/+}$, or C57BL6/SV129 $S C a M C-3^{-1-}$ mice and nonbrain tissue was used for determination of DNA genotype. Neurons represented $>80 \%$ of the total cell population (Ramos et al., 2003; Pardo et al., 2006) and included both glutamatergic and GABAergic neurons (results not shown).

Determination of glucose, lactate, and pyruvate. Glucose, lactate, and pyruvate determinations in media from neuronal cell cultures were performed as follows. Cortical neurons were cultured in 12-well plates for 10 DIV and the experiment was performed in free-serum B27supplemented neurobasal-A medium with $5 \mathrm{~mm}$ glucose. Aliquots of the medium were collected at various times (up to $2 \mathrm{~h}$ ). Lactate content was determined enzymatically (Cuezva et al., 1982; Sánchez-Cenizo et al., 2010). Glucose and pyruvate concentrations in the media were determined by using kits from Boehringer (glucose) and Instruchemie BV (pyruvate) following the manufacturer's instructions in 48-well microplates, with a FLUOstar OPTIMA reader in the absorbance mode. The consumption of glucose, pyruvate, and net formation of lactate by the cells was calculated on the basis of cellular protein. Results are mean \pm SEM $(n=7-15)$ of two to four independent experiments. Data were statistically evaluated by one-way ANOVA followed by Student's $t$ test. Comparisons between control and aralar-deficient cultures were significant where indicated ${ }^{* *} p \leq 0.001$.

Cytosolic $\mathrm{Na}^{+}$and $\mathrm{Ca}^{2+}$ imaging in primary neuronal cultures. Neurons growing on poly-lysine-coated coverslips were loaded with $5 \mu \mathrm{M}$ Fura-2 $\mathrm{AM}$ and $50 \mu \mathrm{M}$ pluronic acid $\mathrm{F} .127$ (Invitrogen) for $30 \mathrm{~min}$ at $37^{\circ} \mathrm{C}$ in $\mathrm{Ca}^{2+}$-free HCSS ( $120 \mathrm{~mm} \mathrm{NaCl}, 0.8 \mathrm{MgCl}_{2}, 25 \mathrm{~mm}$ HEPES, $5.4 \mathrm{~mm} \mathrm{KCl}$, $\mathrm{pH}$ 7.4), $2.5 \mathrm{~mm}$ glucose, and washed for $30 \mathrm{~min}$ in $\mathrm{HCSS}\left(2 \mathrm{~mm} \mathrm{CaCl}_{2}\right.$, $2.5 \mathrm{~mm}$ glucose). Then coverslips were mounted on the microscope stage equipped with a $40 \times$ objective as described previously (Ruiz et al., 1998) and Fura-2 fluorescence was imaged ratiometrically using alternate excitation at 340 and $380 \mathrm{~nm}$, and a $510 \mathrm{~nm}$ emission filter with a Neofluar $40 \times / 0.75$ objective in an Axiovert 75M microscope (Zeiss). Additions were made as a bolus or, for isosmotic high $\mathrm{K}^{+}$, changing to a "isosmotic" HCSS in which $30 \mathrm{~mm} \mathrm{NaCl}$ was replaced by $30 \mathrm{~mm} \mathrm{KCl}(90 \mathrm{~mm}$ $\mathrm{NaCl}, 0.8 \mathrm{MgCl}_{2}, 25 \mathrm{~mm}$ HEPES, $35.4 \mathrm{~mm} \mathrm{KCl}, \mathrm{pH}$ 7.4) during continuous superfusion $(\approx 1.5 \mathrm{ml} / \mathrm{min}) .\left[\mathrm{Ca}^{2+}\right]_{\mathrm{i}}$ and $\left[\mathrm{Na}^{+}\right]_{\mathrm{i}}$ imaging was performed as described with Fura-2 as $\mathrm{Ca}^{2+}$ indicator (Ruiz et al., 1998; Pardo et al., 2006) and sodium-binding benzofuran isophthalate (SBFI) as a sodium indicator (Rose and Ransom, 1997) at $37^{\circ} \mathrm{C}$. For single-cell analysis of $\left[\mathrm{Ca}^{2+}\right]_{\mathrm{i}}$ and $\left[\mathrm{Na}^{+}\right]_{\mathrm{i}}$ the ratio of fluorescence intensity at 340 $\mathrm{nm}\left(\mathrm{F}_{(340)}\right)$ and $380 \mathrm{~nm}\left(\mathrm{~F}_{(380)}\right)\left(\mathrm{F}_{(340)} / \mathrm{F}_{(380)}\right)$ was obtained. Signal calibration for Fura-2 $\left[\mathrm{Ca}^{2+}\right]_{\mathrm{i}}$ imaging $\mathrm{Ca}^{2+}$ was performed with $1 \mu \mathrm{M}$ Br-A23 $\mathrm{Ca}^{2+}$ ionophore (Sigma-Aldrich), with (Rmin) or without (Rmax) preincubation with 2 mM EGTA. Neuronal fluorescence at both wavelengths was corrected for autofluorescence after digitoninpermeabilization and quenching of Fura-2 fluorescence with $4 \mathrm{~mm}$ $\mathrm{MnCl}_{2}$ Ratio measurements were converted to $\mathrm{Ca}^{2+}$ concentrations as described previously (Grynkiewicz et al., 1985). $\mathrm{Na}^{+}$imaging was performed as previously described (Rose and Ransom, 1997), briefly, $20 \mu \mathrm{M}$ SBFI-AM was loaded during $90 \mathrm{~min}$ in the presence of $50 \mu \mathrm{M}$ pluronic acid F.127 in HCSS $2 \mathrm{mM} \mathrm{CaCl}_{2}$ then washed and equilibrated for another $30 \mathrm{~min}$. Monensin $(10 \mu \mathrm{M})$ and ouabain $(0.1 \mathrm{~mm})$ were added for equilibration of extra- and intracellular $\left[\mathrm{Na}^{+}\right]$at the end of the experiments. Image acquisition was performed with the Aquacosmos 2.5 software (Hamamatsu) and data analysis was done with Origin software (OriginLab). When required, BAPTA loading was performed in $\mathrm{Ca}^{2+}$-free HCSS, $50 \mu \mathrm{M}$ BAPTA-AM coloaded with Fura-2 AM during $30 \mathrm{~min}$, then washed and equilibrated in $\mathrm{HCSS} 2 \mathrm{mM} \mathrm{CaCl}_{2}$ medium for another $30 \mathrm{~min}$.

Mitochondrial $\mathrm{Ca}^{+2}$ and cytosolic ATP imaging. To image mitochondrial $\mathrm{Ca}^{2+}$ and cytosolic ATP levels cells were plated onto 4-well Lab-Tek chamber slides and transfected using Effectene (Qiagen) $24 \mathrm{~h}$ prior the experiments either with the plasmid coding for mitochondrially targeted ratiometric GEM-GECO-1 (Addgene plasmid 32461), or with the plasmid coding for Cyt GO-ATeam 1 (kindly provided by Dr. H. Imamura, Kyoto University, Japan), respectively, and processed as previously described (Zhao et al., 2011; Nakano et al., 2011). Experiments were performed in $2.5 \mathrm{~mm}$ glucose HCSS with either $2 \mathrm{mM} \mathrm{CaCl}_{2}$ or $100 \mu \mathrm{m}$ EGTA. Additions were made as a bolus or by changes in the medium composition during continuous superfusion. Cells were excited for 100 $\mathrm{ms}$ at $436 / 20 \mathrm{~nm}$ for Mit-GEM-GECO1 and at 485/27 nm for GOATeam 1, and the emitted fluorescence was collected through a dual pass dichroic CFP-YFP (440-500 and 510-600 nm) alternatively at 480/40 $\mathrm{nm}$ (CFP) and 535/30 nm (YFP) for Mit-GEM-GECO-1, and through a FF495-Di03 dichroic at 520/35 nm (GFP) and 567/15 nm (OFP) for GO-ATeam probe. Images were collected every $5 \mathrm{~s}$ using a filter wheel (Lambda 10-2, Sutter Instruments; all filters purchased from Chroma) and recorded by a Hamamatsu C9100-02 camera mounted on an Axiovert $200 \mathrm{M}$ inverted microscope equipped with a $40 \times / 1.3$ Plan-Neofluar 
Table 1. Glucose utilization in WT and aralar KO cultured neurons

\begin{tabular}{lllll}
\hline Genotype & $\begin{array}{l}\text { Glucose consumed } \\
(\mu \mathrm{mol} / \mathrm{mg} / \mathrm{h})\end{array}$ & $\begin{array}{l}\text { Lactate net form } \\
(\mu \mathrm{mol} / \mathrm{mg} / \mathrm{h})\end{array}$ & $\%$ Lac/Gluc & $\begin{array}{l}\text { Pyr consumed } \\
(\mu \mathrm{mol} / \mathrm{mg} / \mathrm{h})\end{array}$ \\
\hline WT & $0.87 \pm 0.211$ & $1.09 \pm 0.22$ & 1.25 & $1.26 \pm 0.07$ \\
aralar K0 & $0.64 \pm 0.17$ & $1.03 \pm 0.31$ & 1.54 & $1.74 \pm 0.08^{* * *}$
\end{tabular}

Cortical neurons were cultured for 9-10 DIV (days in vitro) and subsequently incubated for $24 \mathrm{~h}$ in free-serum B27-supplemented neurobasal-A medium with $10 \mathrm{~mm}$ glucose. Experiments were performed at a final glucose concentration of $5 \mathrm{~mm}, 240 \mu \mathrm{m}$ lactate, and $367 \mu \mathrm{m}$ pyruvate. Results are mean \pm SEM $(n=7-15)$ of two to four independent experiments. Data were statistically evaluated by one-way ANOVA followed by Student's $t$ test. Comparisons between control and ARALAR-deficient cultures were significant where indicated; ${ }^{* * *} p \leq 0.001$.

objective. Mit-GEM-GECO1 emission ratio was CFP/YFP, whereas GOATeam emission ratio was OFP/GFP reflecting mitochondrial $\mathrm{Ca}^{2+}$ and cyt ATP levels, respectively. For Mit-GEM GECO1 imaging ROIs were selected on mitochondrial-containing areas (identified based on their morphology). Single-cell fluorescence recordings were analyzed using ImageJ (NIH) or MetaMorph (Universal Imaging). When required, 50 $\mu \mathrm{M}$ BAPTA-AM (Sigma-Aldrich) loading was performed in $\mathrm{Ca}^{2+}$-free HCSS during $30 \mathrm{~min}$, and then washed and equilibrated in HCSS $2 \mathrm{~mm}$ $\mathrm{CaCl}_{2}$ for another $30 \mathrm{~min}$.

Measurement of cellular oxygen consumption. Cellular oxygen consumption rate (OCR) was measured using a Seahorse XF24 Extracellular Flux Analyzer (Seahorse Bioscience; Qian and Van Houten, 2010). Cortical primary neuronal were plated in XF24 V7 cell culture at $1.0 \times 10^{5}$ cells/well and incubated for $10 \mathrm{~d}$ in a $37^{\circ} \mathrm{C}, 5 \% \mathrm{CO}_{2}$ incubator in serumfree B27-supplemented neurobasal medium with high levels of glucose. To study OCR at lower glucose concentrations, cultures were preconditioned for $24 \mathrm{~h}$ in serum-free B27-supplemented neurobasal-A media with $10 \mathrm{~mm}$ glucose, with medium changes every $12 \mathrm{~h}$. Cells were equilibrated with bicarbonate-free low-buffered DMEM medium (without pyruvate, lactate, glucose, glutamine, and $\mathrm{Ca}^{2+}$ ) supplemented with 15 , 5 , or $2.5 \mathrm{~mm}$ glucose and $2 \mathrm{~mm} \mathrm{CaCl}_{2}$ or $100 \mu \mathrm{M}$ EGTA in conditions of $\pm \mathrm{Ca}^{2+}$, for $1 \mathrm{~h}$ immediately before extracellular flux assay. In experiments with isosmotic high $\mathrm{K}^{+}$, cultures were first preconditioned for 20 min in $5 \mathrm{~mm}$ glucose HCSS in the presence or absence of $2 \mathrm{~mm} \mathrm{CaCl} 2$. Then, neurons were either maintained in the same medium or stimulated with $30 \mathrm{~mm} \mathrm{KCl}$ in $5 \mathrm{~mm}$ glucose in $\mathrm{Ca}^{2+}$-containing or $\mathrm{Ca}^{2+}$-free isosmotic HCSS medium in which $30 \mathrm{~mm} \mathrm{NaCl}$ was replaced by $30 \mathrm{~mm} \mathrm{KCl}$ for $25 \mathrm{~min}$ before starting respirometry experiments. Calibration of the respiration took place after the vehicle injection in port A. BAPTA-AM was used at $50 \mu \mathrm{M}$ in experiments with veratridine and carbachol in DMEM medium or $10 \mu \mathrm{M}$ BAPTA-AM in the case of isosmotic $\mathrm{KCl}$ stimulation in HCSS medium. Loading was performed in $\mathrm{Ca}^{2+}$-free in bicarbonate-free media or HCSS media for 20-30 min, and then washed and equilibrated in $2 \mathrm{~mm} \mathrm{CaCl}_{2}$ medium for another 25-30 min. Substrates were prepared in the same medium in which the experiment was conducted and were injected from the reagent ports automatically to the wells at the times indicated. Mitochondrial function in neurons was determined through sequential addition of $6 \mu \mathrm{M}$ oligomycin, $0.5 \mathrm{~mm} 2,4-$ dinitrophenol, and $1 \mu \mathrm{M}$ antimycin/1 $\mu \mathrm{M}$ rotenone. This allowed determination of basal oxygen consumption, oxygen consumption linked to ATP synthesis (ATP), non-ATP linked oxygen consumption (leak), mitochondrial uncoupled respiration (MUR), and nonmitochondrial oxygen consumption (NM; Qian and Van Houten, 2010; for review, see Brand and Nicholls, 2011).

\section{Results}

\section{Glucose utilization in WT and aralar KO and SCaMC-3 KO cultured neurons}

Glucose consumption and net lactate formation were measured in culture media from neuronal cultures at 9 DIV using $5 \mathrm{~mm}$ glucose over 30-120 min incubation period (Table 1). ARALAR deficiency decreased glucose consumption (by 1.35-fold, $p=0.4$, Student's $t$ test, $n=7-15$ ) but did not change lactate formation, unlike previous results obtained using higher glucose concentrations (Pardo et al., 2011). As a result, the percentage of glucose converted into lactate (\%Lac/Gluc) tended to increase in aralar
KO neurons. In addition, pyruvate consumption was significantly increased, by 1.39 -fold ( $p=0.00047$, Student's $t$ test), in aralar KO neurons (Table 1). These results show that neurons depend on ARALAR for malate/aspartate shuttle activity and glucose oxidation as previously described (Pardo et al., 2011). Glucose utilization and lactate production were the same in SCaMC3 -WT and SCaMC-3-KO neurons $(1.10 \pm 0.11$ and $1.20 \pm 0.13$ micromoles glucose $\times$ mg prot $^{-1} \times \mathrm{h}^{-1}$, and $1.6 \pm 0.2$ and $2.2 \pm$ $0.4 \mu$ moles lactate $\times$ milligrams prot $^{-1} \times \mathrm{h}^{-1}$ in SCaMC-3-WT and SCaMC-3-KO, respectively).

\section{Bioenergetic characterization of control and aralar $\mathrm{KO}$ and SCaMC-3-KO cultured neurons}

We next analyzed the respiratory activity in intact primary neuronal cultures by using a Seahorse XF24 extracellular flux analyzer (Qian and Van Houten, 2010). The basic setup of these experiments and the information obtained is shown in a graphic form in Figure $1 A$. In control experiments 2,4-dinitrophenol was titrated to obtain the maximum activity of the electron transport chain (data not shown). In other set of controls oligomycin was omitted to correct for its possible effects on the estimation of the maximal uncoupled coupled respiration (Brand and Nicholls, 2011). Under the assay conditions used, no effects of oligomycin on maximal uncoupled respiration were observed (data not shown).

The influence of $\mathrm{Ca}^{2+}$ on respiration was addressed by conducting the experiments in the presence and absence of $2 \mathrm{~mm}$ $\mathrm{CaCl}_{2}$ in the incubation medium (Fig. $1 \mathrm{~B}, E$ ). The relative roles of ARALAR-MAS and SCaMC-3 in the stimulation of OCR were studied by using primary neuronal cultures derived from aralar (Fig. $1 A-E$ ) or SCaMC-3-KO mice (Fig. $1 C, D, F$ ). To control for the variations among the parental mouse strains, the wild-type condition in experiments with ARALAR- or SCaMC-3-deficient neurons was that of the specific parental strain (aralar WT or SCaMC-3-WT, respectively). Figure $1 G, H$ illustrates the profiles obtained from WT and aralar KO cultures with $2.5 \mathrm{~mm}$ glucose in the presence or absence of $\mathrm{Ca}^{2+}$ and in the presence or absence of $2 \mathrm{~mm}$ pyruvate. The behavior of SCaMC-3-KO neuronal cultures was similar to that of WT neurons (Fig. 1D).

\section{MUR}

MUR in cultured neurons reflects the maximal respiratory capacity of neuronal mitochondria in intact neurons. It is not affected by the control exerted by proton reentry either through ATP synthase or the proton leak. It is mainly controlled by substrate supply, by the intrinsic respiratory capacity of mitochondria, and by nonmitochondrial respiration (Brand and Nicholls, 2011). Nonmitochondrial respiration was subtracted to calculate MUR and other mitochondrial respiratory parameters.

MUR was found to increase with the glucose concentration (Fig. $1 B, C$ ) and was higher in the presence than absence of $\mathrm{Ca}^{2+}$. The lack of ARALAR caused a drastic decrease in MUR, both in $\mathrm{Ca}^{2+}$-free and $\mathrm{Ca}^{2+}$-containing media, at all glucose concentrations, dropping to $20 \%$ of WT values at $2.5 \mathrm{~mm}$ glucose (Fig. $1 B$; in the presence of $\mathrm{Ca}^{2+}$ MUR was $667.94 \pm 114.36$ in WT vs $154.63 \pm 31.39$ in aralar KO neurons, Student's $t$ test, $p=0.009$ ), which is consistent with the limitation in glucose-derived pyruvate supply to mitochondria when the major NADH shuttle system fails. Indeed, exogenous pyruvate (but not lactate, results not shown) supply, which bypasses the limitation imposed by the lack of MAS, did not change MUR in the presence of $\mathrm{Ca}^{2+}$ (a nonsignificant 1.23-fold increase; Fig. $1 G, I$ ) but increased it significantly, by $\sim 2.17$-fold both in the presence and 1.93 -fold in 

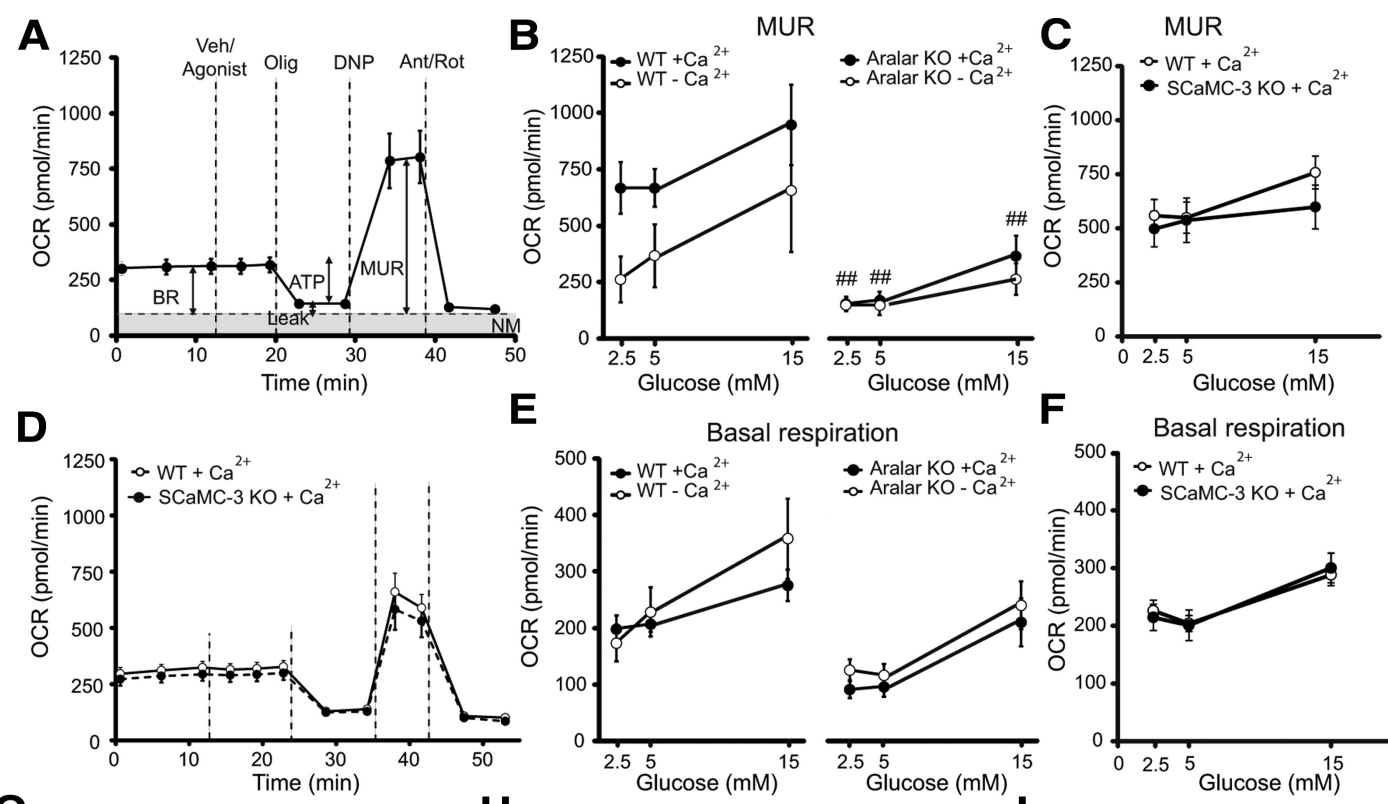

$F$
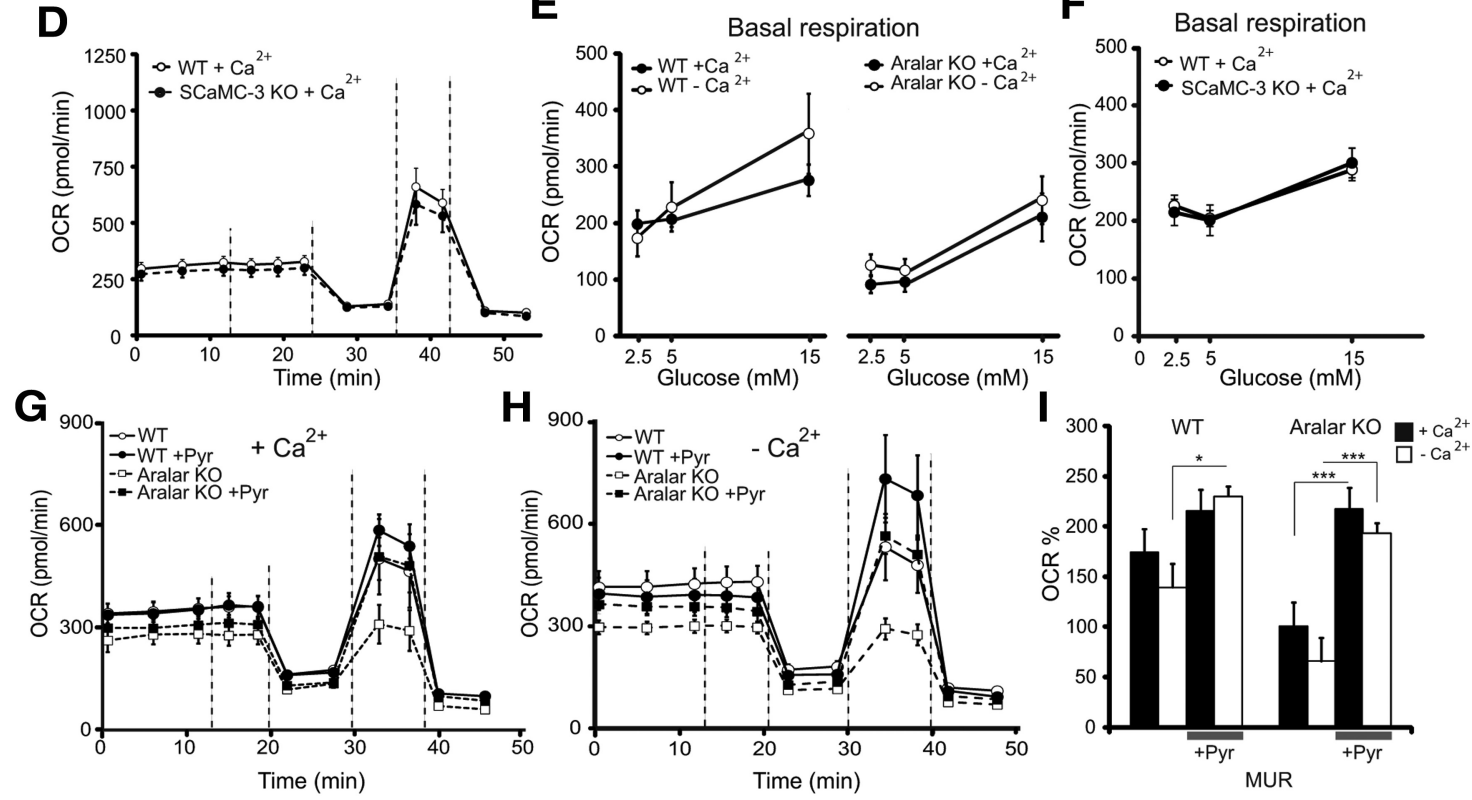

Figure 1. Bioenergetic characterization of aralar WT, aralar K0, SCAMC-3-WT, and SCaMC-3-KO cultured neurons. A, Representative pharmacological profile of oxygen consumption rate in aralar WT neurons showing the sequential injection of agonist/vehicle (Veh) and metabolic inhibitors: oligomycin (0lig, $6 \mu \mathrm{m}$ ), 2,4-dinitrophenol (DNP, $0.5 \mathrm{~mm}$ ) and antimycin A/rotenone (Ant/Rot, 1.0 $\mu \mathrm{M} / 1.0 \mu \mathrm{M}$ ) at different time point indicated by dashed lines which allows the determination of basal oxygen consumption (BR), oxygen consumption linked to ATP synthesis (ATP), non-ATP linked oxygen consumption (Leak), maximal uncoupled respiration (MUR) and nonmitochondrial oxygen consumption (NM) as represented graphically. $\boldsymbol{B}, \boldsymbol{C}$, Effect of glucose and Ca ${ }^{2+}$ on maximal uncoupled respiration (MUR) in aralar WT vs aralar KO neurons and SCaMC-3-WT versus SCaMC-3-KO neurons. D, 0xygen consumption rate in SCaMC-3-WT versus K0 neurons in 2.5 mM glucose, 2 $\mathrm{mm} \mathrm{Ca}{ }^{2+} . E, F$, Effect of glucose and $\mathrm{Ca}^{2+}$ on basal respiration capacity in aralar WT versus aralar K0 and SCaMC-3-WT versus SCaMC-3-KO neurons. Results are means \pm SEM of $3-11$ experiments. The effect of $\mathrm{Ca}^{2+}$ on MUR was significant for aralar WT ( $p<0.05$, two-way ANOVA) but not aralar KO neurons, and the lack of ARALAR caused a significant decrease in MUR at all glucose concentrations in the absence $\left(p<0.05\right.$, two-way ANOVA) or presence of $\mathrm{Ca}^{2+}\left(p<0.001\right.$, two-way ANOVA; \#\#p $<0.01$, post hoc Bonferroni test). Glucose, but not $\mathrm{Ca}{ }^{2+}$, had a significant effect on basal respiration both in aralar WT ( $p<0.01$, two-way ANOVA) and aralar KO neurons $(p<0.001$, two-way ANOVA) and the lack of ARALAR caused a significant decrease in basal respiration both in the presence $\left(p<0.001\right.$, two-way ANOVA) or absence $\left(p<0.01\right.$, two-way ANOVA) of $\mathrm{Ca}^{2+} . \mathbf{G}, \boldsymbol{H}, 0$ xygen consumption profile in aralar WT and aralar K0 cultures in $2.5 \mathrm{~mm}$ glucose medium supplemented with $2 \mathrm{~mm}$ pyruvate (Pyr) in the presence and absence of $2 \mathrm{~mm} \mathrm{Ca}^{2+} . I$, MUR in the presence or absence of $2 \mathrm{~mm}$ pyruvate, expressed as percentage of basal $0 C R$ in aralar WT and aralar KO neurons $\left(n=3-11\right.$ experiments, Student's $t$ test; $\left.{ }^{*} p \leq 0.05,{ }^{* * *} p \leq 0.001\right)$. Data are expressed as mean \pm SEM. Statistical analysis was performed using STATISTICA, version7, StatSoft.

the absence of $\mathrm{Ca}^{2+}(p=0.0009$ and $p=0.00013$ respectively, Student's $t$ test) in aralar KO neurons (Fig. $1 G-I$ ). We did not find any effect of $10 \mathrm{~mm}$ lactate on MUR in WT or aralar KO neurons (results not shown). This may be due to the strong cytosolic acidification induced by the uptake of lactic acid (Álvarez et al., 2003) which may inhibit glycolysis. Therefore, the effect of lactate has not been studied any further.

As indicated above (Fig. 1B), MUR tended to be higher in the presence than in the absence of external $\mathrm{Ca}^{2+}$ at every glucose concentration. This could reflect an effect of cytosolic $\mathrm{Ca}^{2+}$ on substrate supply, perhaps by activating the malate aspartate shuttle. Indeed, the effect of $\mathrm{Ca}^{2+}$ on MUR was no longer present in ARALAR-deficient neurons especially at the physiological glucose concentrations of 2.5 and $5 \mathrm{~mm}$. On the other hand pyruvate increases MUR in aralar $\mathrm{KO}$ neurons regardless of the presence of $\mathrm{Ca}^{2+}$ while in control neurons this effect is less prominent and only in $\mathrm{Ca}^{2+}$-free media (Fig. $1 G-I$ ). Indeed, as the presence of the uncoupler prevents $\mathrm{Ca}^{2+}$ uptake in mitochondria and $\mathrm{Ca}^{2+}$ - activation of pyruvate dehydrogenase, it is expected to result in a $\mathrm{Ca}^{2+}$-independent respiration on pyruvate. These results are consistent with recent reports showing that removal of the components of the mitochondrial $\mathrm{Ca}^{2+}$ uniporter complex (MCU, MICU1, MCUR1) does not change MUR (Baughman et al., 2011; Mallilankaraman et al., 2012a,b) whereas preventing IP3mediated $\mathrm{Ca}^{2+}$ signals does reduce MUR (Cárdenas et al., 2010).

\section{Basal respiration}

Basal respiration rates increased with glucose concentration in $\mathrm{WT}$, aralar $\mathrm{KO}$, and SCaMC-3-KO neurons, and this was independent of the presence of $\mathrm{Ca}^{2+}$ (Fig. 1E). This is unexpected because the $\mathrm{Km}$ for hexokinase is very low, $0.05 \mathrm{~mm}$ (Grossbard and Schimke, 1966), but could be related to mild osmotic changes with higher glucose level. The presence or absence of $2 \mathrm{~mm}$ pyruvate did not change basal respiration in $2.5 \mathrm{~mm}$ glucose in WT, aralar $\mathrm{KO}$, or SCaMC-3-KO neurons (Fig. $1 G, H$, and results not shown). 
Remarkably with $2.5 \mathrm{~mm}$ glucose, a concentration close to that normally present in cerebral extracellular fluid in vivo (Lewis et al., 1974), absolute OCR in aralar KO neuronal cultures, was reduced by $46.13 \pm 7.46 \%(p=0.0067$, Student's $t$ test $)$ with respect to WT or SCaMC-3-KO neuronal cultures (Fig. $1 E, F$ ). The decrease in OCR in aralar KO neurons persisted at all glucose concentrations indicating that the lack of MAS prevents adequate glucose-derived substrate supply to mitochondria also under basal conditions. However, the fact that basal respiration still proceeds even if halved, suggests the existence of other shuttle systems in these neurons. The participation of mitochondrial ATP synthesis in basal respiration is estimated from the decrease in respiration after the addition of oligomycin. Respiration in the presence of oligomycin reflects the proton leak but as ATP synthase inhibition results in a slight mitochondrial hyperpolarization and the proton leak is voltage-dependent, this approach underestimates ATP synthesis and exaggerates the real proton leak (Brand and Nicholls, 2011). With these caveats, the percentage of OCR involved in ATP synthesis in WT and aralar KO neurons in $2.5 \mathrm{~mm}$ glucose was the same, $73.92 \pm 1.20 \%$, and the corresponding proton leak is $26.08 \pm 1.20 \%$, with an "apparent" mitochondrial respiratory control ratio (ATP synthesis/proton leak) of $3.63 \pm 0.56$. The presence of pyruvate or the absence of SCaMC-3 (results not shown) did not change the apparent respiratory control ratios (RCR) under basal conditions, but it should be noted that both SCaMC-3-WT and SCaMC-3-KO neurons had higher apparent RCR values with respect to aralar WT or aralar KO neurons, of $5.1 \pm 0.48$ (SCaMC-3-WT) and $6 \pm 0.3$ $(S C a M C-3-K O)$ in $2 \mathrm{mM} \mathrm{Ca}^{2+}$ medium, and of $6.08 \pm 0.28$ $(S C a M C-3-W T)$ and $5.85 \pm 1.01(S C a M C-3-K O)$ in $\mathrm{Ca}^{2+}$-free medium, these differences should be consequence of the different parental mouse strains.

\section{Effect of agonists on regulation of OCR}

Having shown that in neurons using 2.5-5 mM glucose, basal respiration is not limited by substrate supply, we next studied the control of respiration by agents able to increase neuronal workload. Any increase in workload is followed by ATP breakdown and ADP production which is expected to increase OCR. We used veratridine and high $\mathrm{K}^{+}$which increase workload after plasma membrane depolarization through increases in cytosolic $\mathrm{Na}^{+}$ and $\mathrm{Ca}^{2+}$ and stimulation of the $\mathrm{Na}^{+}-\mathrm{K}^{+}$ATPase, $\mathrm{Na}^{+} / \mathrm{Ca}^{2+}$ exchange and the sarcoendoplasmic reticulum $\mathrm{Ca}^{2+}$-ATPase (SERCA) and plasma membrane $\mathrm{Ca}^{2+}$-ATPase (PMCA) pumps. It is expected that in the presence, but not absence, of external $\mathrm{Ca}^{2+}, \mathrm{Ca}^{2+}$-regulation of respiration would contribute to the increase in OCR in response to these workloads. It has been proposed that even $\mathrm{Ca}^{2+}$ alone, not ATP demand, stimulates mitochondrial bioenergetics in some neuronal types (Chouhan et al., 2012).

Another way to increase workload is through agents causing $\mathrm{Ca}^{2+}$-mobilization from intracellular stores. The increase in cytosolic $\mathrm{Ca}^{2+}$ will cause ATP breakdown by SERCA and PMCA pumps and would be expected to increase OCR. ATP utilization to recover the resting state is much smaller than that caused by $\mathrm{Na}^{+}$entry (Attwell and Laughlin, 2001) and consequently, the OCR response should be also smaller. Moreover, removal of external $\mathrm{Ca}^{2+}$ in this condition will reduce $\mathrm{Ca}^{2+}$ signals and workload at the same time.

In either workload condition, $\mathrm{Ca}^{2+}$ may activate OCR by activating ARALAR-MAS and/or SCaMC-3, by way of increasing substrate or adenine nucleotide supply to mitochondria, and $\mathrm{Ca}^{2+}$ may enter mitochondria through the recently identified
MCU (Baughman et al., 2011; De Stefani et al., 2011), increasing $\mathrm{NADH}$ production in mitochondria and oxidative phosphorylation (Glancy and Balaban, 2012). These mechanisms differ in their $\mathrm{S}_{0.5}$ values for $\mathrm{Ca}^{2+}$-activation, $\sim 300 \mathrm{~nm}$ for ARALAR/ AGC1 (Pardo et al., 2006) and in the micromolar range for both SCaMC-3 (Amigo et al., 2013) and MCU (Drago et al., 2011). The relative roles of these pathways in the stimulation of OCR were studied by using primary neuronal cultures derived from aralar or SCaMC-3-KO mice. To control for the variations among the parental mouse strains, the wild-type condition in experiments with ARALAR- or SCaMC-3deficient neurons was that of the specific parental strain (aralar WT or SCaMC-3-WT, respectively).

\section{Veratridine-induced increase in respiration is activated by $\mathrm{Ca}^{2+}$ and results in a drop in ATP levels}

The lipophilic alkaloid neurotoxin, veratridine, binds buried sites in the voltage-dependent $\mathrm{Na}^{+}$channels in the matrix of the lipid bilayer (Strichartz et al., 1987), causing $\mathrm{Na}^{+}$channels to remain open, and a pronounced increase in intracellular $\mathrm{Na}^{+}$concentration (Rose and Ransom, 1997). The plasma membrane depolarization produced by veratridine opens voltage-dependent $\mathrm{Ca}^{2+}$ channels allowing $\mathrm{Ca}^{2+}$ inflow (Rego et al., 2001). Figure 2 shows the effects of veratridine in cortical neurons. Veratridine $(50 \mu \mathrm{M})$ produced a large and sustained increase in $\left[\mathrm{Ca}^{2+}\right]_{\mathrm{i}}$ which was prevented in $\mathrm{Ca}^{2+}$-free media (Fig. $2 \mathrm{~A}, B$ ). It also induced a sustained rise in mitochondrial $\mathrm{Ca}^{2+}$ levels, reported by mit-GEMGECO-1, a genetically coded $\mathrm{Ca}^{2+}$ sensor expressed in the mitochondrial matrix (Zhao et al., 2011) which was completely absent in $\mathrm{Ca}^{2+}$-free media (Fig. 2D,E). Cytosolic ATP levels, measured with the low affinity FRET cytosolic ATP sensor GOATeam1 (Nakano et al., 2011), were found to drop after veratridine exposure, particularly in $\mathrm{Ca}^{2+}$-free media (Fig. $2 G-I$ ). Veratridine induced a sharp increase in OCR of mouse cortical neurons, as previously observed in synaptosomes (Brand and Nicholls, 2011) which resulted in $180.21 \pm 4.76 \%$ (aralar WT) to $255.02 \pm 11.01 \%$ (SCaMC-3-WT) increase over basal levels (Figs. 2J, $3 E-G$ and $A-C$, respectively). The increase was due to coupled respiration and proton leak, as apparent respiratory control values (Figs. $2 L, 3 D, H$ ) did not change significantly after veratridine addition in $\mathrm{Ca}^{2+}$ media.

In the absence of $\mathrm{Ca}^{2+}$, the increase in OCR induced by veratridine was greatly reduced (Figs. $2 J, 3 B, F$ ). Proton leak values after veratridine exposure were higher in the presence than in the absence of $\mathrm{Ca}^{2+}$ in the external medium, as reflected in the higher $\mathrm{RCR}$ in $\mathrm{Ca}^{2+}$-free than $\mathrm{Ca}^{2+}$-containing medium (Figs. $2 L, 3 D$, $H)$. This is likely due to the existence of $\mathrm{Ca}^{2+}$ cycling across the inner mitochondrial membrane through $\mathrm{MCU}, \mathrm{H}^{+} / \mathrm{Ca}^{2+}, \mathrm{Na}^{+}$/ $\mathrm{Ca}^{2+}$, and $\mathrm{H}^{+} / \mathrm{Na}^{+}$exchangers (Nicholls, 2005).

The veratridine-induced increase in OCR in $\mathrm{Ca}^{2+}$-free media is driven by the increase in cytosolic $\mathrm{Na}^{+}$coupled to ATP demand. In the presence of $\mathrm{Ca}^{2+}$, the increase in OCR induced by veratridine is even higher, whereas ATP levels dropped significantly less (Fig. 2I). This may be caused by (1) the increases in cytosolic $\mathrm{Na}^{+}$and $\mathrm{Ca}^{2+}$ which could result in a further increase in ATP demand in the presence of $\mathrm{Ca}^{2+}$, or (2) the absence of $\mathrm{Ca}^{2+}$-dependent regulation of respiration in $\mathrm{Ca}^{2+}$-free media. To tell apart these possibilities, neurons were preincubated with the rapid intracellular $\mathrm{Ca}^{2+}$-chelator BAPTA-AM (Abramov and Duchen, 2008) and challenged with veratridine in the presence of $\mathrm{Ca}^{2+}$. BAPTA loading blunts cytosolic $\mathrm{Ca}^{2+}$ signals but does not change $\mathrm{Ca}^{2+}$ inflow through voltage-dependent $\mathrm{Ca}^{2+}$ channels (Adler et al., 

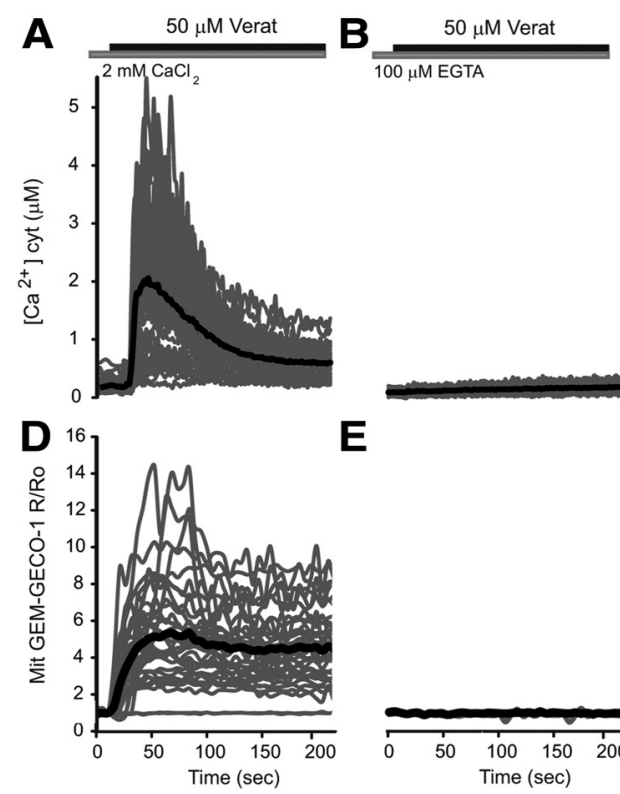

E
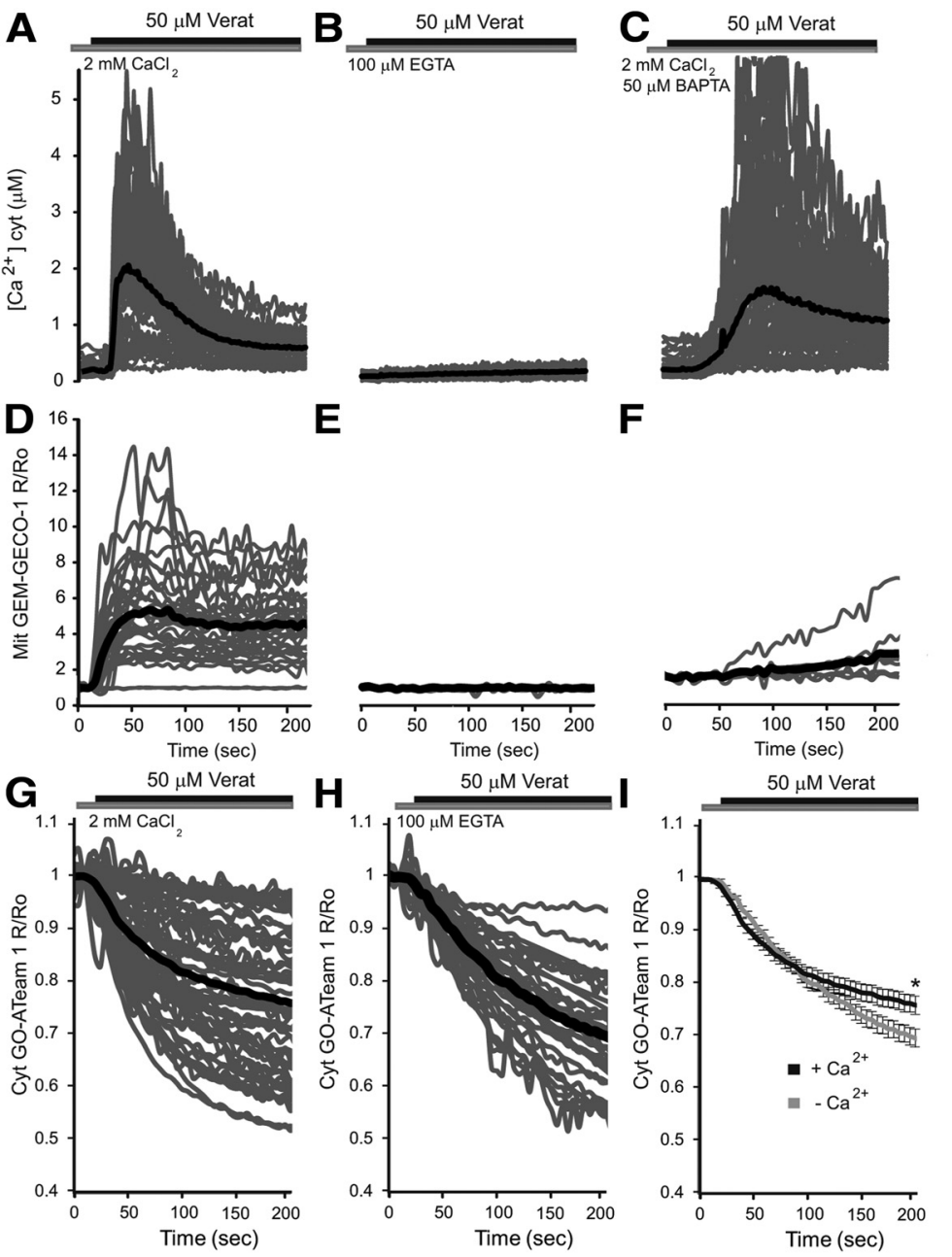

$\mathbf{J}$
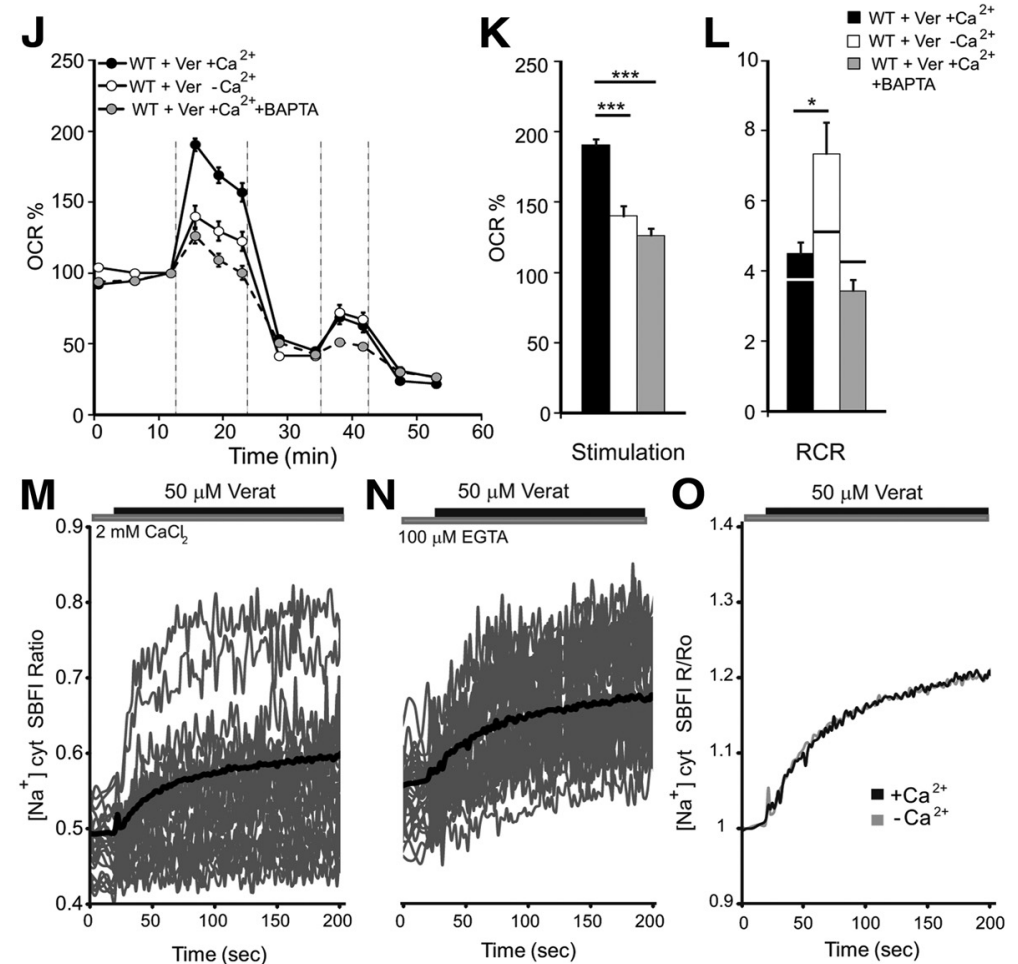

Figure 2. Changes in cytosolic and mitochondrial $\mathrm{Ca}^{2+}$, cytosolic ATP, oxygen consumption and cytosolic $\mathrm{Na}^{+}$in primary neuronal cultures in response to veratridine. $A-C$, Changes in $\left[\mathrm{Ca}^{2+}\right]_{\mathrm{cyt}}$ in Fura-2 loaded neurons obtained by stimulation with 50 $\mu \mathrm{m}$ Veratridine (Ver or Verat) in $2 \mathrm{~mm} \mathrm{Ca}^{2+}, \mathrm{Ca}^{2+}$-free medium, or $50 \mu \mathrm{m}$ BAPTA preloaded neurons in $2 \mathrm{~mm} \mathrm{Ca}^{2+}$ medium. $\boldsymbol{D}-\boldsymbol{F}$,
1991), conditions under which the $\mathrm{Ca}^{2+}$-dependent fraction of the global workload induced by veratridine is maintained. In BAPTA-AM $\left(\begin{array}{lll}50 & \mu \mathrm{M}\end{array}\right)$ loaded neurons $\mathrm{Ca}^{2+}$ signals in the cytosol, and specially in mitochondria, only appeared gradually and after a substantial delay (Fig. 2A,C) and veratridine-stimulation of OCR was severely decreased (Fig. $2 J$ ), indicating that $\mathrm{Ca}^{2+}$-signaling is clearly required for veratridine-induced stimulation of respiration in $\mathrm{Ca}^{2+}$-medium.

We also tested whether the $\mathrm{Na}^{+}$dependent fraction of workload induced by veratridine was maintained in the absence or presence of $\mathrm{Ca}^{2+}$. Intracellular $\mathrm{Na}^{+}$was measured in neurons loaded with SBFI-AM, the $\mathrm{Na}^{+}$indicator (Rose and Ransom, 1997; Fig. 2M-O). As initial SBFI ratios are slightly higher in $\mathrm{Ca}^{2+}$-free than in $\mathrm{Ca}^{2+}$-containing medium, they were normalized to the initial SBFI ratio. Figure $2 \mathrm{O}$ clearly shows that the absence of $\mathrm{Ca}^{2+}$ did not modify veratridine-induced $\mathrm{Na}^{+}$influx. As veratridine-induced drop in cytosolic ATP was still more pronounced in $\mathrm{Ca}^{2+}$-free media, together the results suggest that the lack of $\mathrm{Ca}^{2+}$-regulation of OCR prevents an adequate regeneration of ATP to meet.

Veratridine- and $\mathrm{Ca}^{2+}$-dependent stimulation of respiration is blunted in the absence of SCaMC- 3 and ARALAR The stimulatory effect of veratridine was different in WT and SCaMC-3-KO neu-

$\leftarrow$

Corresponding data in neurons transfected with Mit-GEM-GECO1 probeto determinechanges in $\left[\mathrm{Ca}^{2+}\right]_{\text {mit }}$. Recordings fromatleast 60 cells per condition and two independent experiments were used for $\left[\mathrm{Ca}^{2+}\right]_{\mathrm{i}}$ and a minimum of 15 cells and eight independent experiments for $\left[\mathrm{Ca}^{2+}\right]_{\text {mit }}$ imaging. Individual cell recordings (gray) and average (thick black trace) were shown. G-I, Cytosolic ATP in neurons transfected with cyt-G0-ATeam 1 stimulated with veratridine in $2 \mathrm{~mm} \mathrm{Ca}^{2+}$ medium, $\mathrm{Ca}^{2+}$-free medium plus 100 $\mu \mathrm{M}$ EGTA and comparison of the two conditions. Recordings from individual cells (gray) and average (black) are shown. The drop of ATP values with respect to basal levels 200 s after veratridine addition were $23.9 \pm 1.70 \%$ in the presence and $30 \pm 1.69 \%$ in the absence of $\mathrm{Ca}^{2+}\left({ }^{*} p=0.017\right.$ two-tailed unpaired Student's $t$ test). J, Veratridine-induced stimulation of OCR in aralar WT neurons under the mentioned $\mathrm{Ca}^{2+}$ and BAPTA conditions. $K, L$, ,Stimulation of respiration (as percentage of basal values) and RCR. RCR in nonstimulated state are represented with horizontal lines for each experimental condition ( $n=9-11$ experiments one-way ANOVA, ${ }^{*} p \leq 0.05,{ }^{* * *} p \leq 0.001$, posthoc Bonferronitest). $\boldsymbol{M}, \mathbf{N}$, Changes in $\left[\mathrm{Na}^{+}\right]_{\mathrm{i}}$, in SBFl-loaded neurons by stimulation with 50 $\mu \mathrm{m}$ veratridine in $2 \mathrm{~mm} \mathrm{Ca}{ }^{2+}$ medium or $\mathrm{Ca}^{2+}$-free medium ( $\sim 90$ neurons per condition). 0 , Comparison between response in $\mathrm{Ca}^{2+}$ medium (black trace) and $\mathrm{Ca}^{2+}$-free (gray trace) is shown. Increases in normalized SBFI ratio $200 \mathrm{~s}$ after veratridine were $21.1 \pm 1.02 \%$ and $20.3 \pm 0.81$ in the presence or absence of $\mathrm{Ca}^{2+}$, respectively. 

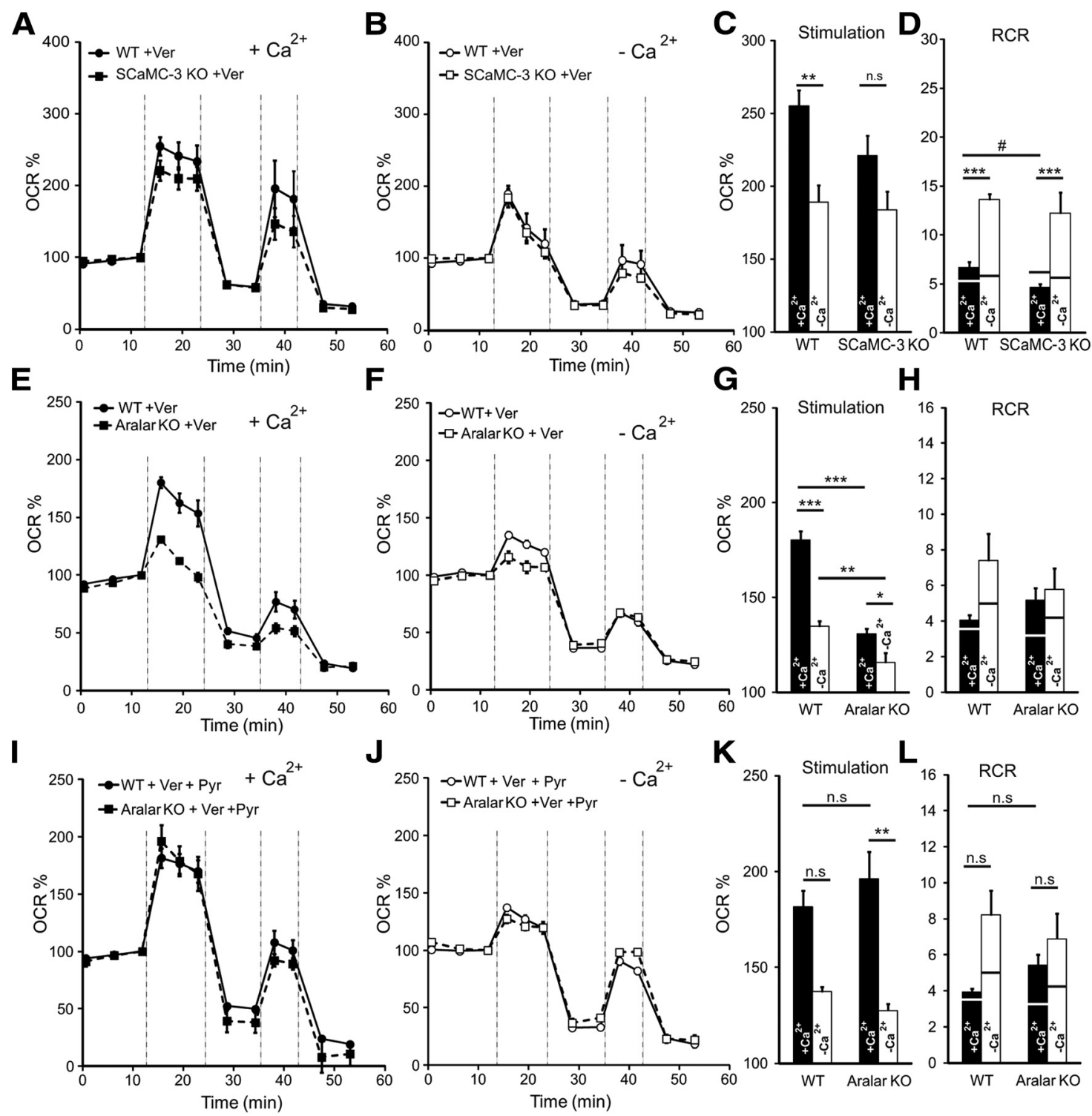

Figure 3. OCR responses to veratridine in ARALAR- and SCaMC-3-deficient neurons. $A-D$, Respiratory profiles in the presence or absence of $2 \mathrm{~mm} \mathrm{Ca}^{2+}$, stimulation of mitochondrial respiration and RCRs of SCaMC-3-WT and SCaMC-3-KO neurons stimulated with $50 \mu \mathrm{m}$ Veratridne (Ver) in $2.5 \mathrm{~mm}$ glucose. E-H, Corresponding data from aralar WT and aralar KO neurons. I-L, Corresponding data for the effect of $2 \mathrm{~mm}$ pyruvate (Pyr) on veratridine-induced mitochondrial respiration in aralar WT and aralar KO neurons. RCR in nonstimulated state are represented with horizontal lines for each experimental condition. Data are expressed as mean \pm SEM from $n=5-6$ experiments in SCaMC-3-WT and SCaMC-3-KO cultures, and from $n=4-12$ experiments in aralar WT and aralar KO cultures. Two-way ANOVA, ${ }^{*} p \leq 0.05 ;{ }^{* *} p \leq 0.01 ;{ }^{* * *} p \leq 0.001$, post hoc Bonferroni test.

rons (Fig. $3 A-D)$. In the presence of $\mathrm{Ca}^{2+}$, the increase in OCR was significantly smaller in $S C a M C-3-K O$ neurons than in controls, but these differences disappeared in $\mathrm{Ca}^{2+}$-free media (Fig. 3C). The requirement for $\mathrm{Ca}^{2+}$ in the effect of SCaMC-3 points to a potential effect of $\mathrm{Ca}^{2+}$-activation of the transporter in the acquisition of a full increase in respiration. This is related with an increase in coupled respiration, as proton leak values are unchanged in SCaMC-3-KO neurons, resulting in significantly higher RCR values in WT than in SCaMC-3-KO neurons (Fig. 3D).

The stimulatory effect of veratridine was strikingly diminished in aralar $\mathrm{KO}$ neurons both in the presence and in the absence of $\mathrm{Ca}^{2+}$ (Fig. $3 E-H$ ). It should be noted that as the basal rates in the aralar $\mathrm{KO}$ cells are about half those of the WT (with or without calcium), the decrease in \%OCR stimulation caused by veratridine shown in Figure $3 E, F$, actually represents a very large difference in absolute OCR. aralar KO neu- rons respond to veratridine in a $\mathrm{Ca}^{2+}$-dependent way (Fig. $3 G)$, thus $\mathrm{Ca}^{2+}$ entry in mitochondria and activation of dehydrogenases together with activation of SCaMC-3 provide the only pathways of $\mathrm{Ca}^{2+}$ regulation of mitochondrial respiration in these neurons.

To analyze whether the lower response to veratridine was due to limited substrate supply to mitochondria, the effect of pyruvate was analyzed in this experimental condition. We found that pyruvate $(2 \mathrm{~mm})$ did not increase veratridinestimulated respiration in WT, but caused an impressive threefold increase in stimulated respiration in aralar $\mathrm{KO}$ neurons (Fig. 3, compare $G$ and $K$ ) reaching stimulation values identical to those of WT neurons both in the absence or presence of $\mathrm{Ca}^{2+}$ (Fig. 3I-L). These results clearly show that the failure to respond to veratridine in aralar $\mathrm{KO}$ neurons is due to substrate limitation imposed by the lack of MAS. 
High $\mathrm{K}^{+}$induced increase in mitochondrial respiration is highly $\mathrm{Ca}^{2+}$-dependent

High extracellular $\mathrm{KCl}$ concentration $(30 \mathrm{~mm})$ depolarizes cell membrane, activating the voltage-sensitive $\mathrm{Na}^{+}$and $\mathrm{Ca}^{2+}$ channels leading to elevation of their cytosolic concentrations in cultured neurons (Courtney et al., 1990; Rose and Ransom, 1997). Channel opening is transient due to the voltage-dependent inactivation of $\mathrm{Na}^{+}$channels but some of the $\mathrm{Ca}^{2+}$ channels remain open under continuous depolarization (Courtney et al., 1990). The increase in cytosolic $\mathrm{Na}^{+}$and $\mathrm{Ca}^{2+}$ levels will activate $\mathrm{Na}^{+}$ and $\mathrm{Ca}^{2+}$ extrusion mechanisms $\left(\mathrm{Na}^{+} / \mathrm{K}^{+}\right.$ATPase pump, SERCA, PMCA, and $\mathrm{Na}^{+} / \mathrm{Ca}^{2+}$ exchangers), which will activate ATP turnover.

Figure $4 A-P$ shows the responses to the addition of $30 \mathrm{~mm} \mathrm{KCl}$ in cortical neurons. $\mathrm{KCl}$ addition produces a pronounced elevation of $\left[\mathrm{Ca}^{2+}\right]_{\mathrm{i}}$ in the presence, but not absence, of external $\mathrm{Ca}^{2+}$, with average $\left[\mathrm{Ca}^{2+}\right]_{\mathrm{i}}$ returning to $\sim 500 \mathrm{~nm}$ in the continuous presence of $\mathrm{KCl}$ (Fig. 4A,B). Mitochondrial $\mathrm{Ca}^{2+}$ levels increase in parallel to those of cytosolic $\mathrm{Ca}^{2+}$ levels, and this increase is absent in $\mathrm{Ca}^{2+}$-free media (Fig. $4 D, E$ ). The results were essentially the same when $\mathrm{KCl}$ addition was performed by isosmotic replacing $\mathrm{Na}^{+}$for $\mathrm{K}^{+}$during continuous superfusion (results not shown).

The changes in cytosolic ATP levels, after isosmotic replacement of $30 \mathrm{mM} \mathrm{Na}^{+}$for $30 \mathrm{mM} \mathrm{K}^{+}$are shown in Figure $4 G-I$. A gradual drop in cytosolic ATP levels is observed in the presence of $\mathrm{Ca}^{2+}$ but greater than that in the absence of $\mathrm{Ca}^{2+}$. When $30 \mathrm{~mm}$ $\mathrm{KCl}$ was added as a bolus, this drop was preceded by a rapid transient increase which was the same in the absence or presence of $\mathrm{Ca}^{2+}$, most likely caused by a hyperosmotic effect, as it is also observed after $30 \mathrm{~mm} \mathrm{NaCl}$ or $60 \mathrm{~mm}$ sucrose addition (results not shown).

The experimental setup of the Seahorse equipment does not allow to add $\mathrm{KCl}$ in an isotonic medium. Therefore, we first evaluated the effect of $30 \mathrm{~mm} \mathrm{KCl}$ addition on OCR in cortical neurons. High potassium produces an immediate increase in OCR of $\sim 183 \%$ (aralar WT neurons; Fig. 4J,K) or 200\% (SCaMC-3-WT neurons, data not shown) over basal values in the presence of 2 $\mathrm{mM} \mathrm{Ca}^{2+}$ but a much smaller increase of $\sim 117 \%$ (aralar WT; Fig. $4 J, K$ ) and $150 \%$ (SCaMC-3-WT, data not shown) respectively, in the absence of $\mathrm{Ca}^{2+}$. This stimulation was stable $>6-9 \mathrm{~min}$ and was not increased in the presence of pyruvate (results not shown). In PC12 cells, $\mathrm{KCl}$ effects on OCR are due to an hyperosmotic response (Ashton and Ushkaryov, 2005). However, in cortical neurons the effects of hyperosmotic $\mathrm{NaCl}$ or sucrose on OCR were much smaller than those of $\mathrm{KCl}$ (results not shown), suggesting that most of the OCR response to $\mathrm{KCl}$ addition is not due to the hyperosmotic effect.

We next evaluated the response to $30 \mathrm{~mm} \mathrm{KCl}$ under isosmotic conditions. Neurons were incubated with isosmotic $30 \mathrm{mM} \mathrm{KCl}$ or control $(5.4 \mathrm{~mm} \mathrm{KCl})$ conditions before OCR determinations were started. As observed, OCR was also increased in isosmotic $30 \mathrm{~mm}$ $\mathrm{KCl}$, but slightly less than in hyperosmotic conditions. $\mathrm{KCl}$ stimulation was also calcium-dependent, $137.55 \pm 8.09 \%$ and $113.97 \pm$ $7.96 \%$ in the presence and absence of $\mathrm{Ca}^{2+}$, respectively (Fig. $4 N$ ). Isosmotic $\mathrm{KCl}$ stimulation significantly increased oligomycinsensitive respiration in the presence of $2 \mathrm{mM} \mathrm{Ca}^{2+}(77.24 \pm 1.64$ and

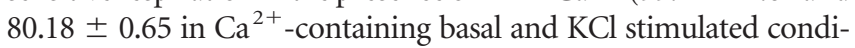
tions, respectively, $p=0.025$, Student's $t$ test).

To investigate the role of $\mathrm{Ca}^{2+}$-regulation of OCR in the response to isosmotic $\mathrm{KCl}$, neurons were preincubated with $10 \mu \mathrm{M}$ BAPTA-AM, and challenged with $\mathrm{KCl}$ in the presence of $\mathrm{Ca}^{2+}$ to maintain the global workload of $\mathrm{K}^{+}$-depolarization in a $\mathrm{Ca}^{2+}$ - medium, while blunting cytosolic $\mathrm{Ca}^{2+}$ signals. Indeed, Figure $4 C, F$ shows that the increases in $\left[\mathrm{Ca}^{2+}\right]_{\mathrm{i}}$ and specially $\left[\mathrm{Ca}^{2+}\right]_{\text {mit }}$ were drastically reduced and delayed under this condition. Interestingly, $\mathrm{KCl}$-stimulation of OCR dropped to the values obtained in $\mathrm{Ca}^{2+}$-free medium (Fig. $4 M, N$ ). By using neurons loaded with SBFI-AM we have found that isosmotic $\mathrm{KCl}$ causes only subtle changes in cytosolic $\mathrm{Na}^{+}$both in the presence or absence of $\mathrm{Ca}^{2+}$ (Fig. 4P), in agreement with previous reports (Rose and Ransom, 1997). This suggests that KCl-induced workload is probably related to the increase in cytosolic $\mathrm{Ca}^{2+}$, whereas increased cytosolic $\mathrm{Na}^{+}$plays a modest role. This is consistent with the findings that (1) KCl-induced fall in cytosolic ATP is hardly detectable in $\mathrm{Ca}^{2+}$-free medium (Fig. $4 \mathrm{G}-\mathrm{I}$ ) and(2) $\mathrm{KCl}-$ stimulation of OCR was much lower in the absence than in the presence of $\mathrm{Ca}^{2+}$ (Fig. 4N). These results clearly indicate that $\mathrm{Ca}^{2+}$-regulation of OCR is absolutely required to reach a full stimulation of coupled respiration by $\mathrm{KCl}$-depolarization.

\section{High $\mathrm{K}^{+}$-stimulation of OCR requires ARALAR-MAS but not SCaMC-3}

Figure $5 \mathrm{~A}-\mathrm{J}$ shows the effects of the lack of SCaMC- 3 or ARALAR on $\mathrm{K}^{+}$-stimulated OCR in cortical neurons under isosmotic conditions. The lack of SCaMC-3 did not modify the response to high $\mathrm{K}^{+}$(Fig. $5 A-C$ ). However, the lack of ARALAR blocked $\mathrm{K}^{+}$stimulation of OCR, both in the presence or absence of $\mathrm{Ca}^{2+}$, suggesting that the $\mathrm{Ca}^{2+}$-mediated stimulation strictly requires ARALAR-MAS. Indeed, although in WT neurons $\mathrm{K}^{+}$-stimulated OCR was not increased any further in the presence of pyruvate (Fig. 5, compare $F$ and $I$ ), the addition of $2 \mathrm{~mm}$ pyruvate, did not change basal OCR but led to a pronounced potentiation of the effects of $\mathrm{K}^{+}$on aralar $\mathrm{KO}$ neuron. In fact, stimulation values were now the same as in WT neurons. These results further indicate that the $\mathrm{Ca}^{2+}$-dependent stimulation of OCR caused by $\mathrm{KCl}$ relies on ARALAR as signaling pathway to mitochondria.

\section{Carbachol induces a $\mathrm{Ca}^{2+}$-dependent increase in respiration levels which requires the ARALAR-MAS pathway}

In cortical neurons, carbachol acts on muscarinic cholinergic, G-protein-coupled receptors, which activate $G_{q / 11}$ and signal through activation of phospholipase $\mathrm{C}$, generation of inositol 3-phosphate $\left(\mathrm{IP}_{3}\right)$ and $\mathrm{Ca}^{2+}$-mobilization from intracellular stores, giving rise to a transient $\left[\mathrm{Ca}^{2+}\right]_{\mathrm{i}}$ peak (Kelly et al., 1996; Lucas-Meunier et al., 2003; Kipanyula et al., 2012). The emptying of the endoplasmic reticulum (ER) $\mathrm{Ca}^{2+}$ stores triggered by $\mathrm{IP}_{3}$ activates $\mathrm{Ca}^{2+}$ entry through low-conductance plasmalemmal channels that are regulated by the level of $\mathrm{Ca}^{2+}$ stored in the ER, a process known as store-operated $\mathrm{Ca}^{2+}$ entry (SOCE; Putney, 2009).

Figure $6 A, B$ shows that $250 \mu \mathrm{M}$ carbachol induced an immediate increase in $\left[\mathrm{Ca}^{2+}\right]_{i}$ also observed in $\mathrm{Ca}^{2+}$-free medium, followed by a new steady-state $\left[\mathrm{Ca}^{2+}\right]_{i}$ value above resting levels in the presence of $\mathrm{Ca}^{2+}$ or to a recovery of the resting state in $\mathrm{Ca}^{2+}$-free media in which SOCE-induced $\mathrm{Ca}^{2+}$ entry does not occur. Carbachol-induced $\left[\mathrm{Ca}^{2+}\right]_{\mathrm{cyt}}$ signals hardly reached mitochondria, as no rise in $\left[\mathrm{Ca}^{2+}\right]_{\text {mit }}$ was detected either in the presence or absence of $\mathrm{Ca}^{2+}$ (Fig. 6D,E). The workload induced by carbachol is much smaller than that involving plasma membrane depolarization and does not lead to any changes in cytosolic ATP levels either in the presence or absence of $\mathrm{Ca}^{2+}$ (Fig. 6F). As ATP is used to restore $\mathrm{Ca}^{2+}$ levels to resting conditions, ATP demand is expected to be drastically reduced in a $\mathrm{Ca}^{2+}$-free medium. Accordingly, carbachol induced an increase in OCR in the presence of $\mathrm{Ca}^{2+}$ but not in its absence (Fig. $6 G-I$ ) but much 

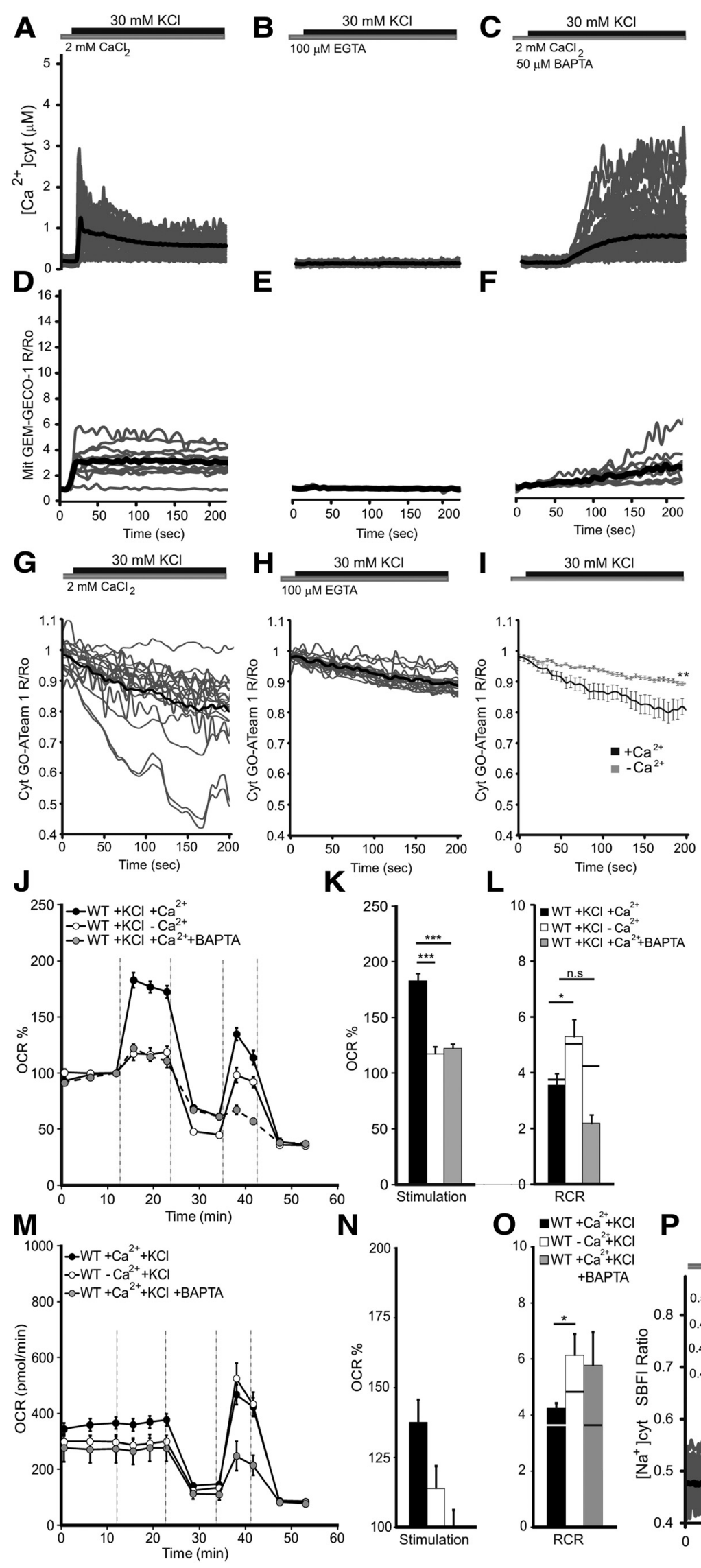

L
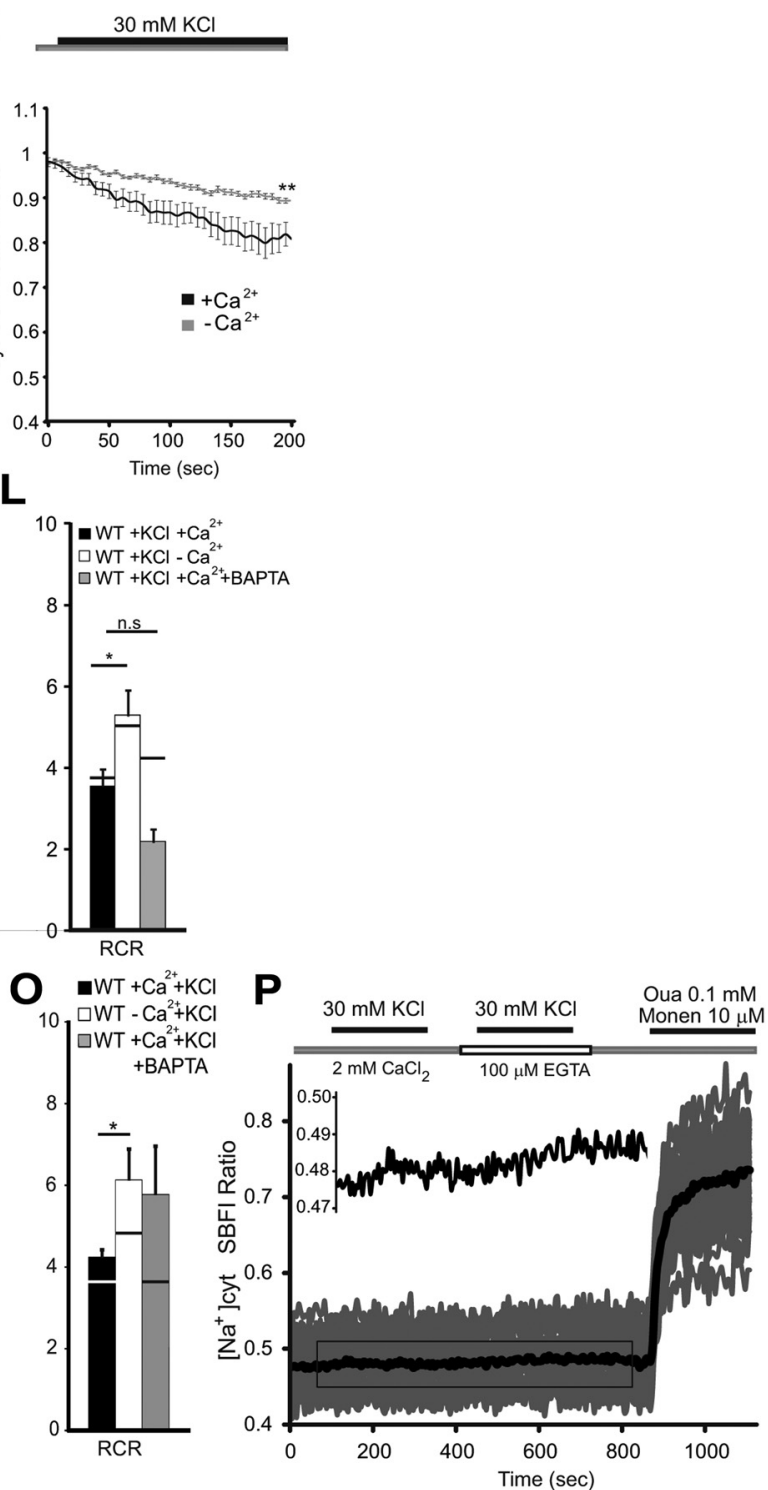

Figure 4. Changes of cytosolic and mitochondrial $\mathrm{Ca}^{2+}$, cytosolic ATP, oxygen consumption, and cytosolic $\mathrm{Na}^{+}$in primary neuronal in response to $\mathrm{KCl} . \mathrm{A}-\mathrm{C}$, $\mathrm{Changes}$ in $\left[\mathrm{Ca}^{2+}\right]_{\mathrm{cyt}}$ in Fura-2loaded neurons obtained by stimulation with $30 \mathrm{~mm} \mathrm{KCl}$ in $2 \mathrm{~mm} \mathrm{Ca}{ }^{2+}, \mathrm{Ca}^{2+}$-free medium, or $50 \mu \mathrm{M}$ BAPTA preloaded neurons in $2 \mathrm{~mm} \mathrm{Ca}{ }^{2+}$ medium. D-F, (Figure legend continues.) 
A
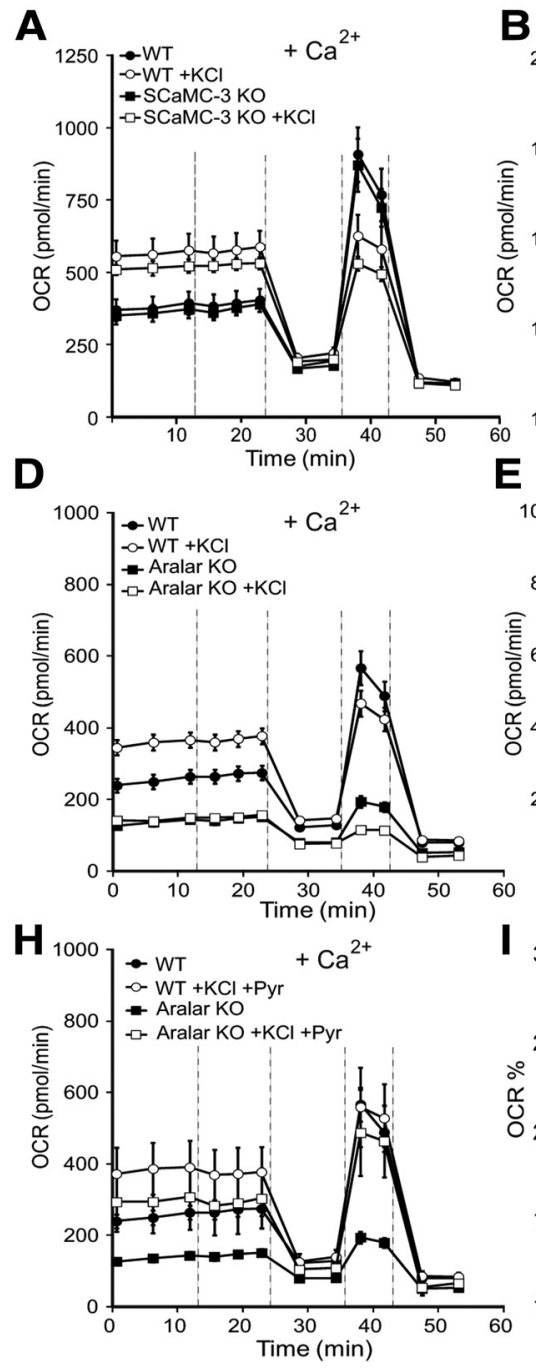

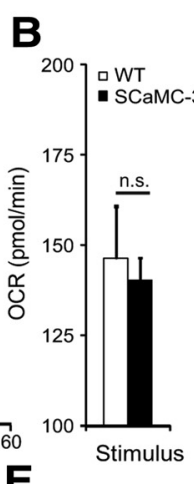

1000 ] $-W T$

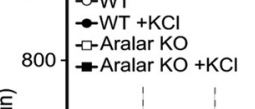

$800+$-Aralar $\mathrm{KO}+\mathrm{KC}$

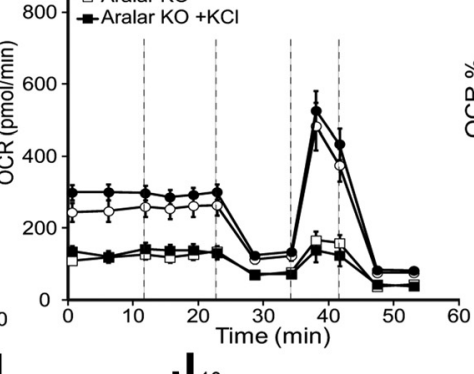

$-\mathrm{Ca}^{2+}$

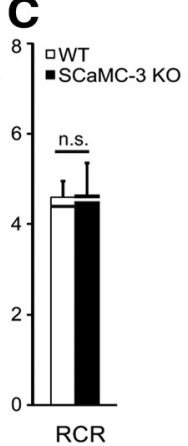

$\mathbf{J}_{10}$

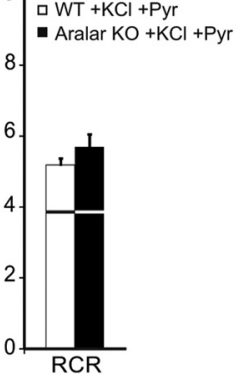

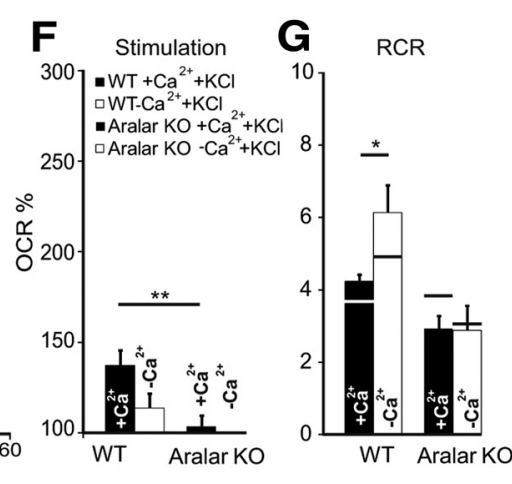

Figure 5. OCR-responses to $30 \mathrm{~mm} \mathrm{KCI} \mathrm{in} \mathrm{ARALAR-} \mathrm{or} \mathrm{SCaMC-3-deficient} \mathrm{cortical} \mathrm{neurons.} \mathrm{A-C,} \mathrm{Respiratory} \mathrm{profiles,} \mathrm{stimulation} \mathrm{of} \mathrm{mitochondrial} \mathrm{respiration,} \mathrm{and} \mathrm{RCRs} \mathrm{of} \mathrm{SCaMC-3-WT} \mathrm{and}$ SCaMC-3-KO neurons stimulated with isosmotic $30 \mathrm{~mm} \mathrm{KCl}$ in the presence of $2 \mathrm{~mm} \mathrm{Ca}^{2+}$. D-G, Corresponding data for aralar WT and aralar KO cultures in the presence or absence of $2 \mathrm{~mm} \mathrm{Ca}^{2+}$. $\boldsymbol{H}-\boldsymbol{J}$, Corresponding data for the effect of $2 \mathrm{~mm}$ pyruvate (Pyr) on isosmotic $30 \mathrm{~mm}$ KCl-induced respiratory stimulation in aralar WT and aralar K0 neurons in the presence of $2 \mathrm{~mm} \mathrm{Ca}^{2+}$. RCR in nonstimulated state are represented with horizontal lines for each experimental condition. Data correspond to 5-6 experiments in SCaMC-3-WT and SCaMC-3-KO cultures and 4-24 experiments in aralar WT and aralar KO respectively (two-way ANOVA, ${ }^{*} p \leq 0.05 ;{ }^{* *} p \leq 0.01 ;$ post hoc Bonferroni test).

(Figure legend continued.) Corresponding data in neurons transfected with Mit-GEM-GEC01 probe to determine changes in $\left[\mathrm{Ca}^{2+}\right]_{\text {mit }}$. Recordings from at least 60 cells per condition and two independent experiments were used for cytosolic $\mathrm{Ca}^{2+}$ imaging and a minimum of 15 cells and eight independent experiments for mitochondrial $\mathrm{Ca}^{2+}$ imaging. Individual cell recordings (gray) and average (black) were shown. $\boldsymbol{G}, \boldsymbol{H}$, Cytosolic ATP levels after a switch from HCSS medium to isosmotic $\mathrm{KCl}$ medium in which $30 \mathrm{~mm} \mathrm{NaCl}$ was replaced by $30 \mathrm{~mm} \mathrm{KCl}$ either in $2 \mathrm{~mm}$ $\mathrm{Ca}^{2+}$ medium or $100 \mu \mathrm{m}$ EGTA medium. I, Comparison between the two conditions. The drop in ATP values 200 s after isosmotic $K C l$ stimulation was $18.6 \pm 0.3 \%$ and $9 \pm 0.1 \%$ with respect to basal levels in the presence and absence of $\mathrm{Ca}^{2+}$, respectively ${ }^{* *} p=0.009$ two-tailed unpaired Student's $t$ test). J-L, Respiratory profiles, stimulation of mitochondrial respiration, and RCRs of neurons stimulated with hyperosmotic $\mathrm{KCl}$ in $2 \mathrm{~mm} \mathrm{Ca}^{2+}, \mathrm{Ca}^{2+}$-free medium or 50 $\mu \mathrm{M}$ BAPTA preloaded neurons in $2 \mathrm{~mm} \mathrm{Ca}^{2+} . \mathbf{M}-\mathbf{0}$, Corresponding data from neurons stimulated with isosmotic $\mathrm{KCl}$ using $10 \mu \mathrm{m}$ BAPTA. RCR in nonstimulated state are represented with horizontal lines for each experimental condition $(n=8-30$ experiments in aralar WT neuronal cultures; one-way ANOVA, ${ }^{*} p \leq 0.05,{ }^{* * *} p \leq 0.001$, post hoc Bonferroni test). $\boldsymbol{P}$, (hanges in $\left[\mathrm{Na}^{+}\right]_{\mathrm{j}}$, in SBFI loaded neurons exposed to 5.4 or $30 \mathrm{~mm}$ isosmotic $\mathrm{KCl}$ in $2 \mathrm{~mm} \mathrm{Ca}^{2+}$ or $100 \mu \mathrm{m}$ EGTA medium as indicated. Monensin (Monen; $10 \mu \mathrm{m}$ ) and Ouabain (0ua; $0.1 \mathrm{~mm}$ ) were added for equilibration of extra- and intracellular $\left[\mathrm{Na}^{+}\right]$at the end of the experiments. Individual cell recordings (gray) and average (black) were shown $(n=29)$. lower than that caused by high $\mathrm{K}^{+}$or veratridine. Carbachol specifically increased oligomycin sensitive respiration from $74.48 \pm 1.97 \%$ to $84.38 \pm 2.21$ in basal and carcachol-induced OCR, respectively.

The role of $\mathrm{Ca}^{2+}$-regulation of OCR with respect to ATP demand in the response to carbachol was evaluated by studying carbachol-stimulation of OCR in the presence of $\mathrm{Ca}^{2+}$ in BAPTA-AM loaded neurons, in which carbachol-induced $\mathrm{Ca}^{2+}$ transients were abolished (Fig. $6 \mathrm{C}$ ), whereas store-operated $\mathrm{Ca}^{2+}$ entry is maintained or increased by preventing its $\mathrm{Ca}^{2+}$-dependent inactivation (Litjens et al., 2004), a situation entailing conservation or even increase of workload in the absence of $\mathrm{Ca}^{2+}$ signaling. After BAPTA loading, carbachol-stimulation of OCR was halved (Fig. $6 G-I)$, indicating that $\mathrm{Ca}^{2+}$ signaling to mitochondria is required to induce the full response to carbachol. Moreover, as the workload and ATP demand may be larger in BAPTA-loaded than control neurons, the real effect of $\mathrm{Ca}^{2+}$ on carbachol stimulation of OCR is probably underestimated.

Figure $7 A-C$ shows that the lack of SCaMC- 3 had no effect on carbachol-induced stimulation of OCR. However, ARALAR de- 
A

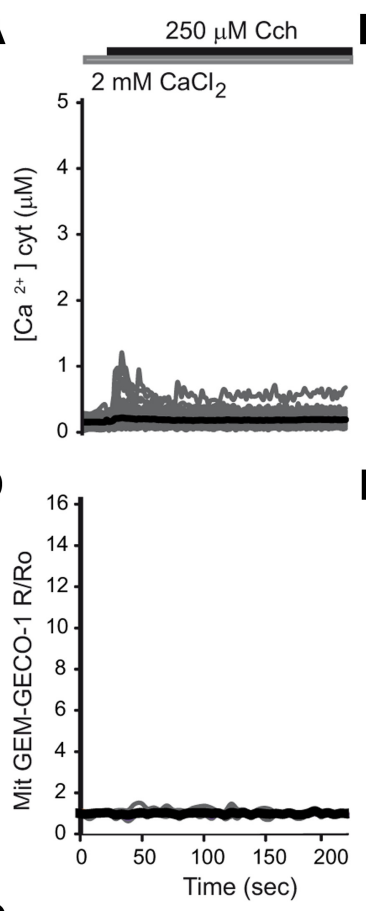

G

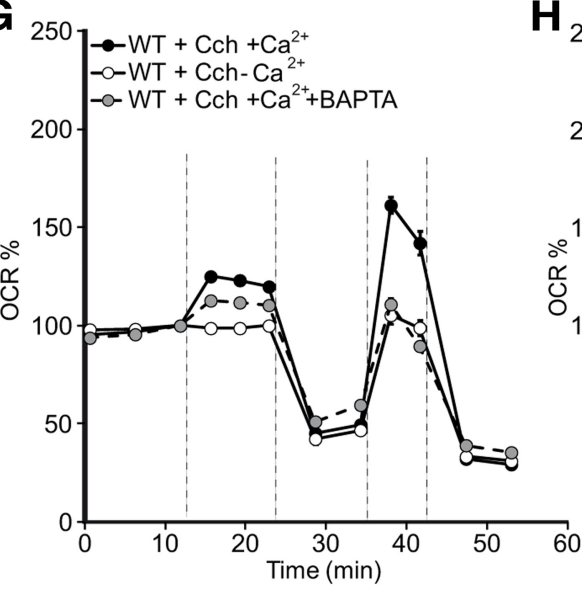

E
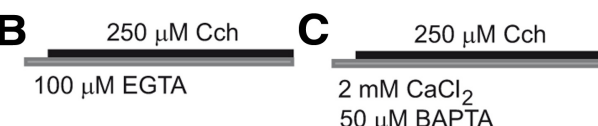

$50 \mu \mathrm{M}$ BAPTA
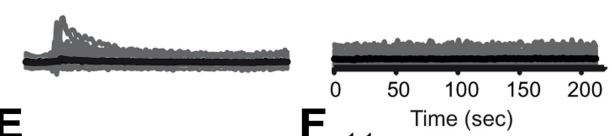

$\mathbf{F}$
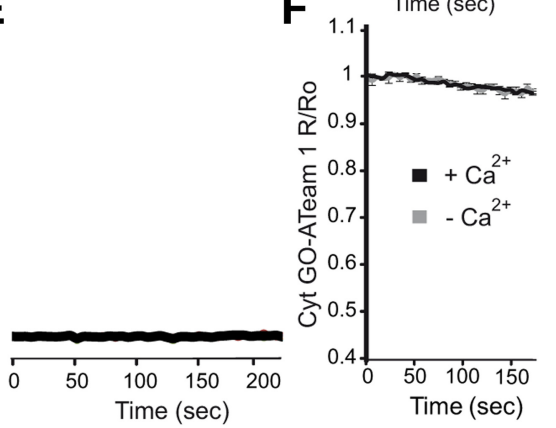

$\mathbf{H}_{250}$

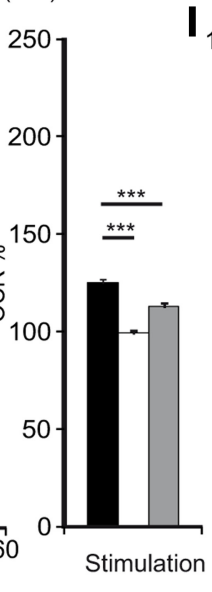

$\mathbf{I}_{10}$

mWT $+\mathrm{Cch}+\mathrm{Ca}^{2+}$ $\square \mathrm{WT}+\mathrm{Cch}-\mathrm{Ca}^{2+}$ $\square \mathrm{WT}+\mathrm{Cch}+\mathrm{c}$

+BAPTA

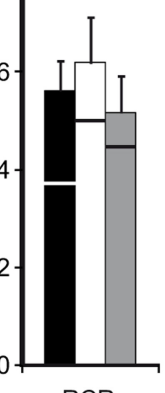

RCR

Figure 6. Changes in cytosolic and mitochondrial $\mathrm{Ca}^{2+}$, cytosolic ATP and oxygen consumption in response to carbachol. $\mathbf{A}-\mathbf{C}$, Changes in $\left[\mathrm{Ca}^{2+}\right]_{\mathrm{cyt}}$ in Fura-2-loaded neurons obtained by stimulation with $250 \mu \mathrm{M}$ Carbachol (Cch) in $2 \mathrm{~mm} \mathrm{Ca}{ }^{2+}, \mathrm{Ca}^{2+}$-free medium, or $50 \mu \mathrm{m}$ BAPTA preloaded neurons in $2 \mathrm{mM} \mathrm{Ca}^{2+}$ medium. $\boldsymbol{D}, \boldsymbol{E}$, Corresponding data in neurons transfected with Mit-GEM-GECO1 to determine changes in $\left[\mathrm{Ca}^{2+}\right]_{\text {mit }}$. Recordings from at least 60 cells per condition and two independent experiments were used for cytosolic $\mathrm{Ca}^{2+}$ and a minimum of 15 cells and eight independent experiments for mitochondrial $\mathrm{Ca}^{2+}$. Individual cell recordings (gray) and average (black) were shown. $\boldsymbol{F}$, Corresponding data for cytosolic ATP in neurons transfected with cyt-G0-ATeam1. Drop in ATP values $200 \mathrm{~s}$ after carbachol addition were $4.9 \pm 0.8 \%$ and $2.1 \pm 0.4 \%$ with respect to basal levels in the presence or absence of $\mathrm{Ca}^{2+}(p=0.92$, two-tailed unpaired Student's $t$ test). $\mathbf{G}-\mathbf{I}$, Respiratory profiles, stimulation of mitochondrial respiration, and RCRs of neurons stimulated with $250 \mu \mathrm{m}$ carbachol in $2 \mathrm{~mm} \mathrm{Ca}^{2+}, \mathrm{Ca}^{2+}$-free medium, or $50 \mu \mathrm{m}$ BAPTA preloaded neurons in $2 \mathrm{~mm} \mathrm{Ca}^{2+}$. RCR in nonstimulated state were represented with horizontal lines for each experimental condition. Data from 18 to 22 experiments in aralar WT cultures (one-way ANOVA, ${ }^{* * *} p \leq 0.001$, post hoc Bonferroni test).

ficiency resulted in a smaller stimulation in the presence of $\mathrm{Ca}^{2+}$ (Fig. $7 D-F$ ) suggesting that under this condition activation of the ARALAR-MAS pathway is required. The lack of ARALAR reflects a limitation in substrate supply to mitochondria, as pyruvate addition abolished the differences in carbachol-stimulation of OCR between ARALAR-deficient and WT neurons (Fig. 7G-I).

The requirement of ARALAR-MAS for the full respiratory response to carbachol in the presence of $\mathrm{Ca}^{2+}$ is possibly mediated through $\mathrm{Ca}^{2+}$-activation of ARALAR in the intermembrane space rather than through changes in matrix $\mathrm{Ca}^{2+}$, as no changes in mitochondrial $\mathrm{Ca}^{2+}$ were observed in response to carbachol, whereas high $\mathrm{K}^{+}$and veratridine caused rapid increases in mito- chondrial $\mathrm{Ca}^{2+}$ in the presence, but not absence, of extracellular $\mathrm{Ca}^{2+}$. The effect of BAPTA on carbachol stimulation of OCR is probably related to its effects in blunting the increase in cytosolic $\mathrm{Ca}^{2+}$ required to activate ARALAR-MAS at the mitochondrial intermembrane space.

\section{Discussion}

The role of $\mathrm{Ca}^{2+}$ in tuning ATP production to ATP demand in excitable cells has been known for a long time (Jouaville et al., 1999; Hayakawa et al., 2005; Glancy and Balaban, 2012; Rizzuto et al., 2012). However, in intact neurons the contribution of $\mathrm{Ca}^{2+}$ in adjusting coupled respiration to ATP demand is still controversial (Hayakawa et al., 2005; Mathiesen et al., 2011). A confounding variable in these studies is the fact that any increase in cytosolic $\mathrm{Ca}^{2+}$, either by uptake from the extracellular space or release from intracellular $\mathrm{Ca}^{2+}$ stores, is necessarily coupled to the use of ATP to restore resting $\mathrm{Ca}^{2+}$ levels.

We have now addressed the following fundamental issues: (1) Are any of the brain $\mathrm{Ca}^{2+}$-regulated mitochondrial carriers ARALAR or SCaMC-3 required in basal or maximal respiration of intact neurons using physiological glucose concentrations? (2) Is $\mathrm{Ca}^{2+}$ signaling (independently of $\mathrm{Ca}^{2+}$ dependent increase in ATP demand) required to upregulate respiration in response to an increase in workload in intact neurons? (3) Are ARALAR or SCaMC-3 limiting such $\mathrm{a} \mathrm{Ca}^{2+}$-dependent upregulation of respiration?

We have first shown that mitochondrial respiration in nonstimulated intact cortical neurons using physiological glucose concentrations $2.5-5 \mathrm{~mm}$ (Lewis et al., 1974) depends on ARALAR-MAS, but not on SCaMC-3, and is reduced by $46 \%$ in neurons lacking ARALAR. This clearly indicates a most important role of ARALAR-MAS in shuttling NADH to mitochondria and providing pyruvate supply to the organelle. The lack of effect of external $\mathrm{Ca}^{2+}$ and exogenous pyruvate in basal respiration confirms that the main factor governing basal OCR is workload, i.e., ATP utilization (Brand and Nicholls, 2011).

We next analyzed the effects of different workloads on OCR under conditions in which $\mathrm{Ca}^{2+}$ signaling was allowed or prevented. These were provided by veratridine, high $\mathrm{K}^{+}$depolarization, and carbachol. In the presence of $\mathrm{Ca}^{2+}$, veratridine causes an increase in cytosolic $\mathrm{Ca}^{2+}$ and $\mathrm{Na}^{+}$concentrations of 2-3 $\mu \mathrm{M}$ (Fig. 2) and $25 \mathrm{~mm}$ (Rose and Ransom, 1997), respectively. As estimated by Attwell and Laughlin (2001), any increase in $\left[\mathrm{Ca}^{2+}\right]_{\mathrm{cyt}}$ from $100 \mathrm{~nm}$ to $2-3 \mu \mathrm{M}$, in which 39 of every $40 \mathrm{Ca}^{2+}$ atoms are buffered (Helmchen et al., 1997), would result in a net increase in ATP consumption of $\sim 0.1 \mathrm{~nm}$ ATP in $1 \mu \mathrm{l}$ cell volume to extrude 
A

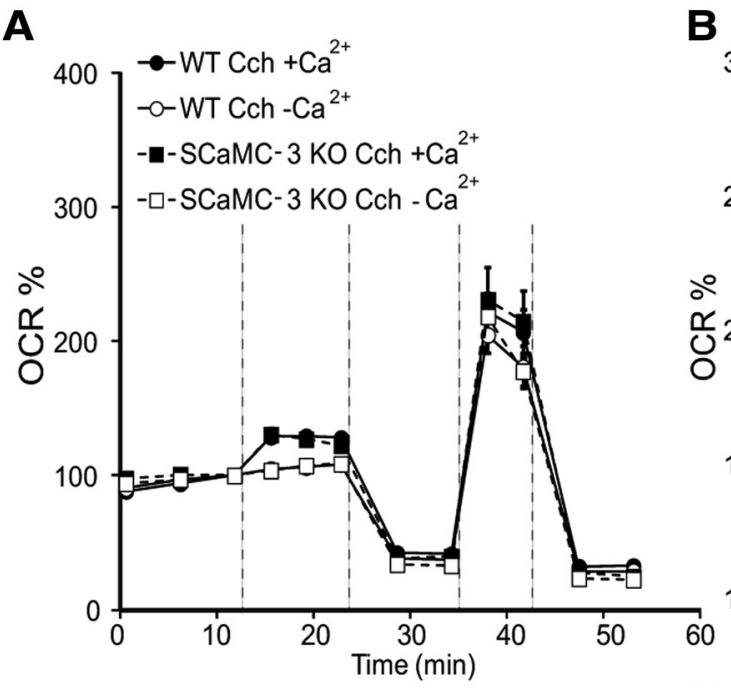

D

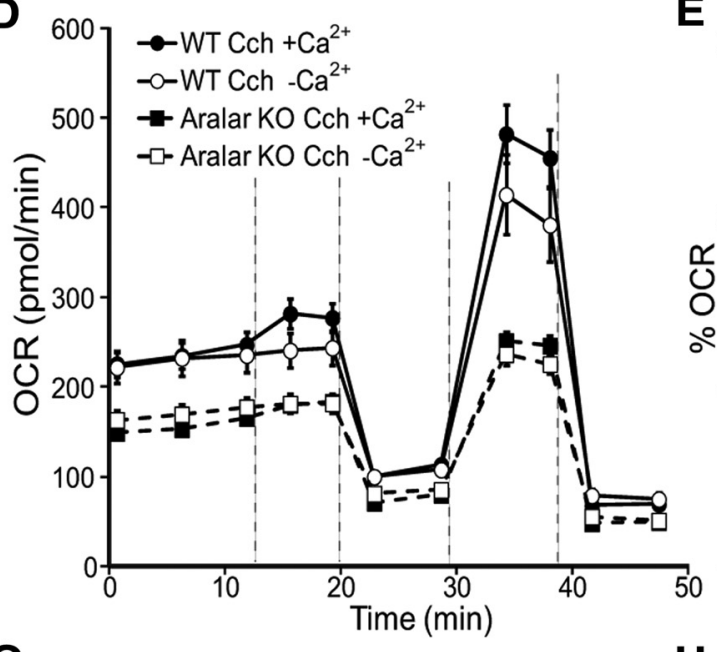

$\mathbf{G}$

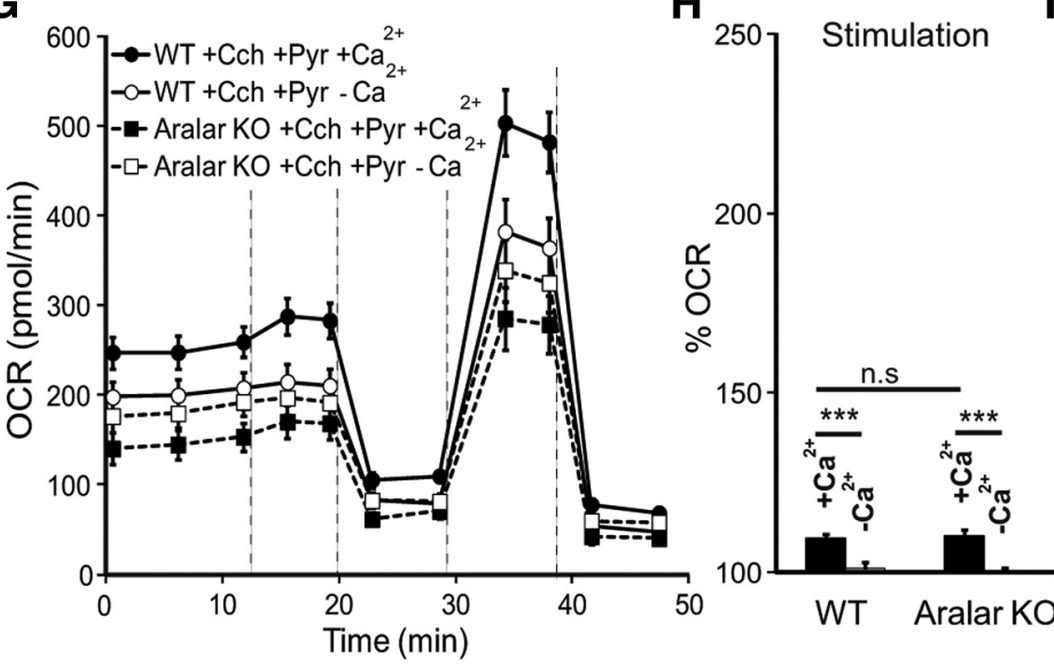

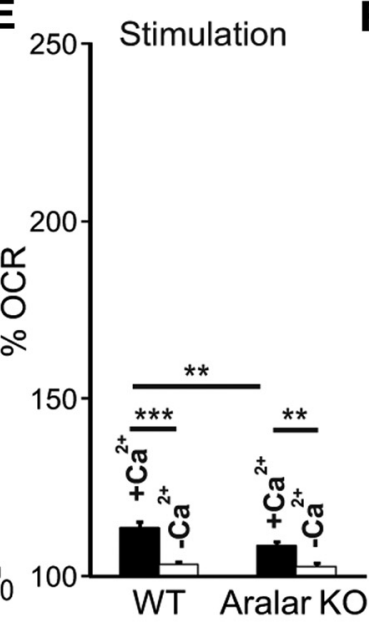

C

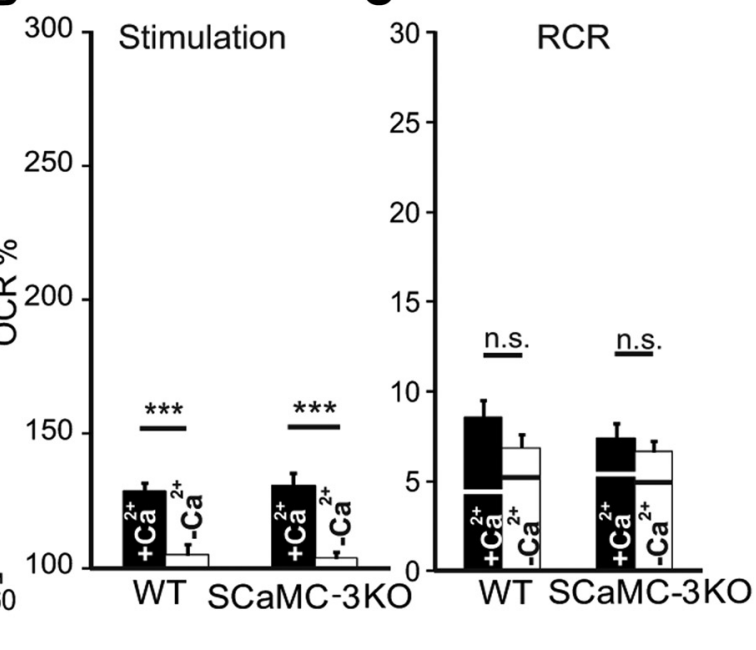

$\mathbf{F}$
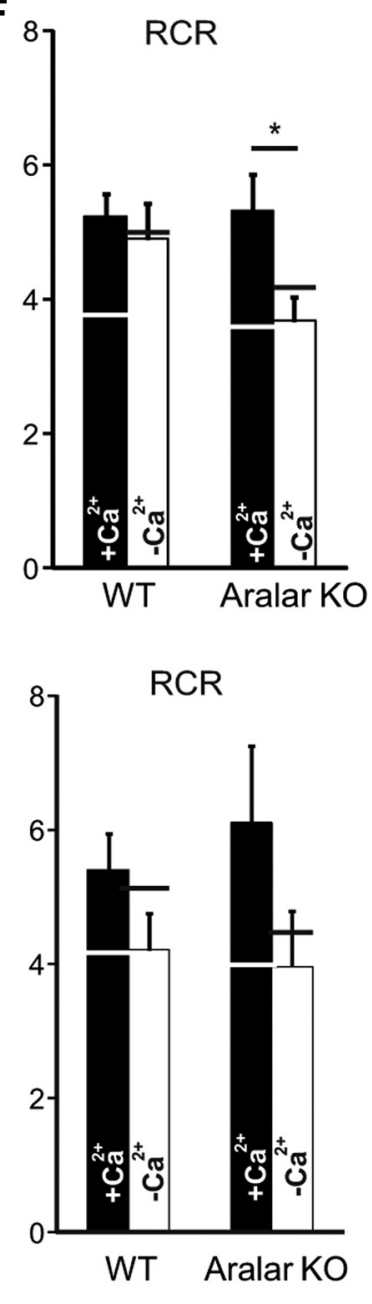

Figure 7. OCR response to Carbachol (Cch) in ARALAR-and SCaMC-3-deficient neuronal cultures. $A-D$, Respiratory profiles in the presence or absence of $2 \mathrm{~mm} \mathrm{Ca}{ }^{2+}$, stimulation of mitochondrial respiration, and RCRs of SCaMC-3-WT and SCaMC-3-KO neurons stimulated with $250 \mu \mathrm{m}$ carbachol in $2.5 \mathrm{~mm}$ glucose. $\boldsymbol{E}-\boldsymbol{H}$, Corresponding data from aralar WT and aralar KO neurons. G-I, Corresponding data of the effect of $2 \mathrm{~mm}$ pyruvate (Pyr) on carbachol-induced mitochondrial respiration in aralar WT and aralar KO neurons. RCR in nonstimulated state are represented with horizontal lines for each experimental condition. Data from 5 to 6 experiments in SCaMC-3-WT and SCaMC-3-K0 cultures, and from 4to 12 experiments in aralar WT and aralarK0 cultures (two-way ANOVA, ${ }^{*} p \leq 0.05 ;{ }^{* *} p \leq 0.01 ;{ }^{* * *} p \leq 0.001$, posthoc Bonferroni test).

$\mathrm{Ca}^{2+}$ at a cost of $1 \mathrm{ATP} / \mathrm{Ca}^{2+}$ by plasma membrane or ER ATPases, and a demand of $\sim 8.3 \mathrm{nM}$ ATP to extrude $\mathrm{Na}^{+}$at a cost of $1 \mathrm{ATP} / 3$ $\mathrm{Na}^{+}$through the $\mathrm{Na}^{+}, \mathrm{K}^{+}$-ATPase, i.e., a total demand of $\sim 8.4 \mathrm{nM}$ ATP, most of which are used for $\mathrm{Na}^{+}$extrusion. In other words, even if the $\left[\mathrm{Ca}^{2+}\right]_{\text {bound }} /\left[\mathrm{Ca}^{2+}\right]_{\text {free }}$ ratio may be higher (Martinez-Serrano et al., 1992), most of the ATP demand is due to $\mathrm{Na}^{+}$entry. Thirty millimoles of $\mathrm{K}^{+}$causes a nondetectable increase in $\left[\mathrm{Na}^{+}\right]_{\mathrm{i}}$ and an increase in $\left[\mathrm{Ca}^{2+}\right]_{\mathrm{i}}$, of $1-2 \mu \mathrm{M}$ (Fig. 4), resulting in total ATP de- 


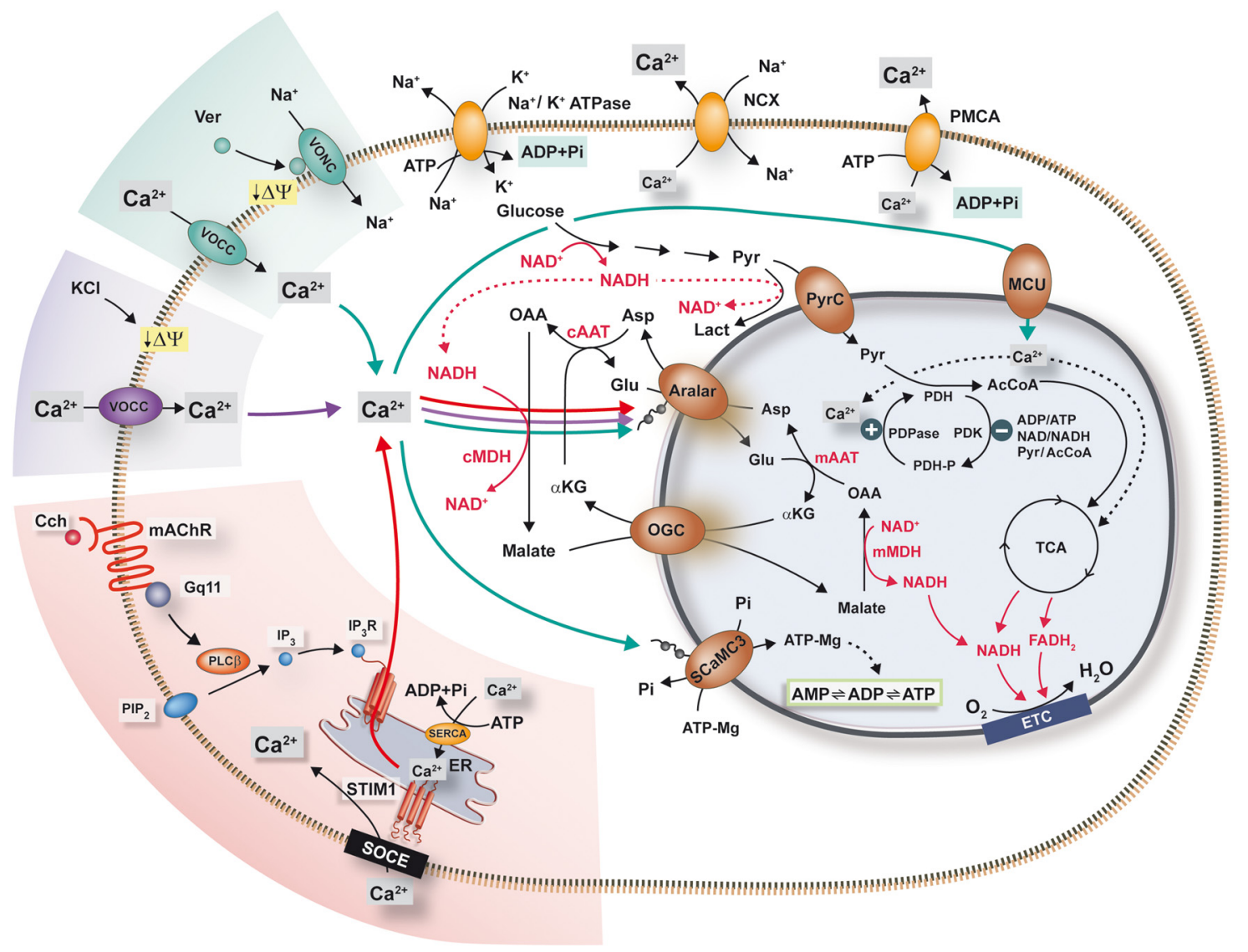

Figure 8. Schematic representation of the effects of the different workloads on $\mathrm{Ca}^{2+}$ regulation of neuronal oxygen consumption. Pathways indicated in green, purple, and red are activated by Veratridine (Ver), $\mathrm{KCl}$, and Carbachol (Cch), respectively. All three stimuli activate ARALAR-MAS, increasing pyruvate supply in mitochondria, whereas only veratridine activates adenine nucleotide uptake through SCaMC-3. Veratridine also stimulates respiration after mitochondrial $\mathrm{Ca}^{2+}$ uptake through the MCU and activation of mitochondrial dehydrogenases. SOCE, Store operated $\mathrm{Ca}^{2+}$ entry; ETC, electron transport chain; AAT,aspartate aminotranferase; AcCoA, acetyl coenzyme A; Asp, aspartate; Cch, carbachol; ER, endoplasmic reticulum; ETC, electron transport chain; Glu, glutamate; $\mathbb{P}_{3}$, inositol trisphosphate; $\mathbb{P}_{3} \mathrm{R}$, inositol 3-phosphate receptor; $\alpha$-KG, $\alpha$-ketoglutarate; mAChR, muscarinic cholinergic G-protein-coupled receptor; $M C U$, mitochondrial calcium uniporter; $\mathrm{MDH}$, malate dehydrogenase; $\mathrm{NCX}$, sodium calcium exchanger; $\mathrm{OAA}$, oxaloacetate; $\mathrm{OGC}$, oxoglutarate carrier; $\mathrm{PDH}$, pyruvate dehydrogenase; PDKase, pyruvate dehydrogenase kinase; PDPase, pyruvate dehydrogenase phosphatase; PIP ${ }_{2}$, phosphatidylinositol 4,5-bisphosphate; PLC- $\beta$, phospholipase C $\beta$; PMCA, plasma membrane calcium ATPase; PyrC, pyruvate carrier; SERCA, sarco/endoplasmic reticulum Ca ${ }^{2+}$-ATPase; SOCE, store-operated calcium entry; TCA, tricarboxylic acid cycle; Ver, veratridine; VOCC, voltage operated calcium channel; VONC, voltage operated sodium channel.

mand of $\sim 0.06-0.08 \mathrm{~nm}$ per microliter of cell volume. For carbachol, with mean increases in $\left[\mathrm{Ca}^{2+}\right]_{\mathrm{i}}$ of $\sim 0.1-0.2 \mu \mathrm{M}$, ATP demand is only due to $\mathrm{Ca}^{2+}$ extrusion and corresponds to $\sim 0.01 \mathrm{nM}$ ATP in $1 \mu \mathrm{l}$ cell volume. In the presence of $\mathrm{Ca}^{2+}$, the response to all three conditions was an immediate increase in oligomycin-sensitive OCR which persisted ( $\mathrm{KCl}$ and carbachol) or declined (veratridine) during the following minutes.

In all cases the OCR response was severely reduced in the absence of $\mathrm{Ca}^{2+}$, a condition that substantially lowers ATP demand in response to $\mathrm{KCl}$ and carbachol, but has a much smaller impact on workload in the case of veratridine, suggesting that lack of $\mathrm{Ca}^{2+}$-regulation rather than lower ATP demand is responsible for the reduced veratridine-stimulation of OCR. Indeed, the decrease in cytosolic ATP levels caused by veratridine is more severe in $\mathrm{Ca}^{2+}$-free media (Fig. 2) indicating that decreased mitochondrial production of ATP, not lower ATP demand, explains the neuronal response to this workload in $\mathrm{Ca}^{2+}$-free medium. All stimuli caused a substantially lower increase in OCR in BAPTA-loaded neurons, in which workload is preserved, clearly indicating that $\mathrm{Ca}^{2+}$-regulation of respiration is required to meet workload demands with an increase in OCR.

We next analyzed the mechanisms responsible for $\mathrm{Ca}^{2+}$. regulation of respiration in the different workloads. For veratridine, the mechanism involved is clearly dependent on $\mathrm{MCU}$ as respiration in aralar $\mathrm{KO}$ neurons still responds to veratridine in a $\mathrm{Ca}^{2+}$. dependent way (Fig. $3 G$ ). In these neurons, $\mathrm{Ca}^{2+}$ entry in mitochondria and activation of dehydrogenases together with activation of SCaMC-3 provide the only pathways of $\mathrm{Ca}^{2+}$-regulation of mitochondrial respiration. As the blunted response to veratridine in aralar KO neurons is reversed by pyruvate supply both in the absence and presence of $\mathrm{Ca}^{2+}$ (Fig. 3), the results suggest that the increase in mitochondrial $\mathrm{Ca}^{2+}$ is insufficient to fully increase respiration upon veratridine challenge and MAS activity to push pyruvate in mitochondria (Gellerich et al., 2009) is clearly required.

On the other hand, the requirement of SCaMC-3 is different, as it is strictly $\mathrm{Ca}^{2+}$-dependent. Isolated brain mitochondria from SCaMC-3 mice exchange $[\mathrm{ATP}-\mathrm{Mg}]^{2-}$ or $[\mathrm{ADPH}]^{2-}$ against $P_{i}^{2-}$ across the inner mitochondrial membrane with an $\mathrm{S}_{0.5}$ for $\mathrm{Ca}^{2+}$ activation of 3-4 $\mu \mathrm{M}$ within the same range of the MCU (Amigo et al., 2013). The uptake of adenine nucleotides stimulated by a large rise in cytosolic $\mathrm{Ca}^{2+}$ may affect mitochondrial function in two ways: by mass action ratio effects on the ATP synthase, causing an increase in coupled respiration as is thought to occur in hepatocytes (Aprille, 1988), or by increasing the $\mathrm{Ca}^{2+}$ retention capacity of mitochondria exposed to high $\mathrm{Ca}^{2+}$ loads 
(Amigo et al., 2013). Further work is required to clarify the mechanism involved.

$\mathrm{Ca}^{2+}$-regulation of OCR in response to $\mathrm{KCl}$ does not require SCaMC-3 but is absolutely dependent on ARALAR-MAS, as no increase in OCR was obtained in aralar KO neurons, whereas exogenous pyruvate allowed restoration of stimulated respiration to control values. As $\left[\mathrm{Ca}^{2+}\right]_{\text {mit }}$ increases in this condition (Fig. $4 D$ ) regardless of ARALAR deficiency (Pardo et al., 2006), these results indicate that $\left[\mathrm{Ca}^{2+}\right]_{\text {mit }}$ by itself is unable to increase respiration in response to this workload. In these conditions, $\left[\mathrm{Ca}^{2+}\right]_{\text {cyt }}$ activation of ARALAR-MAS appears as the only pathway for $\mathrm{Ca}^{2+}$-regulation of respiration in cortical neurons by "pushing" pyruvate into mitochondria, in other words, through an increase in pyruvate transport into mitochondria caused by an increase in cytosolic pyruvate. It is surprising that the increase in $\left[\mathrm{Ca}^{2+}\right]_{\text {mit }}$ is not sufficient to activate pyruvate dehydrogenase $(\mathrm{PDH})$ and other mitochondrial dehydrogenases and thereby "pull" pyruvate into mitochondria as occurs in aralar KO neurons stimulated by veratridine (pyruvate is expected to be pulled into mitochondria through the consumption of pyruvate by $\mathrm{PDH}$ and mass action ratio effects on the pyruvate carrier). Activation of PDH may require not only $\mathrm{Ca}^{2+}$-activation of $\mathrm{PDH}$ phosphatase but inhibition of PDH kinases (PDKs) which inactivate $\mathrm{PDH}$, through increases in mitochondrial pyruvate/acetylCoA and ADP/ATP ratios (Stacpoole, 2012). The high workload induced by veratridine, but not by $\mathrm{KCl}$, associated with a more pronounced increase in mitochondrial ADP/ATP ratio may limit inhibition of PDKs and explain the lack of $\mathrm{KCl}$-stimulated respiration in aralar KO neurons. On the other hand, whether ARALAR-MAS activity is also required to prime mitochondria for $\mathrm{Ca}^{2+}$ stimulation of metabolism is an open question.

Neurons respond to the small workload imposed by carbachol with a modest but sustained increase in OCR. Interestingly, the lack of ARALAR caused a significant decrease in this response in the presence, but not absence, of $\mathrm{Ca}^{2+}$, suggesting that $\mathrm{Ca}^{2+}$ activation ARALAR-MAS is the push mechanism to drive pyruvate in mitochondria upon carbachol exposure. The prominent role of ARALAR-MAS in regulating neuronal respiration in this condition agrees with the small size of the $\mathrm{Ca}^{2+}$ transient and lack of $\left[\mathrm{Ca}^{2+}\right]_{\text {mit }}$ changes caused by carbachol (Fig. 6) and higher affinity of the ARALAR-MAS pathway than MCU for $\mathrm{Ca}^{2+}(300$ nM vs a few $\mu \mathrm{M}$ ), and with the finding of an essential role of AGC1-MAS in increasing mitochondrial $\mathrm{NAD}(\mathrm{P}) \mathrm{H}$ in response to small $\mathrm{Ca}^{2+}$ signals (Pardo et al., 2006).

Together, these results underscore the roles of MCU$\left[\mathrm{Ca}^{2+}\right]_{\text {mit }}$ ARALAR-MAS, and SCaMC-3 in upregulating oligomycin-sensitive respiration in cerebral cortex neurons in response to workloads produced by increases in $\mathrm{Na}^{+}$and/or $\mathrm{Ca}^{2+}$ and robust-to-small $\mathrm{Ca}^{2+}$ signals (Fig. 8). These roles may vary in neurons from the adult brain due to changes in enzyme and transporter composition.

MCU- $\left[\mathrm{Ca}^{2+}\right]_{\text {mit }}$ play a prominent role in the response to the large workload produced by veratridine. The ARALAR-MAS pathway also contributes in the regulation of pyruvate supply to mitochondria in this condition, greatly amplifying the OCR response. The ARALAR-MAS pathway plays an outstanding role in the response to smaller workloads, being the only $\mathrm{Ca}^{2+}$. regulation mechanism responsible for upregulation of respiration in response to the small $\mathrm{Ca}^{2+}$ signals produced by carbachol. Surprisingly, it appears to be also the main mechanism responsible for $\mathrm{Ca}^{2+}$-regulation of respiration in response to $\mathrm{KCl}$, which induces large $\mathrm{Ca}^{2+}$ signals in mitochondria. In all cases,
ARALAR-MAS through the $\mathrm{Ca}^{2+}$-activation of ARALAR in the intermembrane space provides pyruvate to mitochondria. The mitochondrial ATP-Mg/Pi carrier SCaMC-3 limits respiration only in response to high workloads and robust $\mathrm{Ca}^{2+}$ signals which are able to activate carrier activity, as produced by veratridine, suggesting a requirement of adenine nucleotide uptake in mitochondria to generate a full respiratory response under these conditions.

\section{References}

Abramov AY, Duchen MR (2008) Mechanisms underlying the loss of mitochondrial membrane potential in glutamate excitotoxicity. Biochim Biophys Acta 1777:953-964. CrossRef Medline

Adler EM, Augustine GJ, Duffy SN, Charlton MP (1991) Alien intracellular calcium chelators attenuate neurotransmitter release at the squid giant synapse. J Neurosci 11:1496-1507. Medline

Álvarez G, Ramos M, Ruiz F, Satrústegui J, Bogónez E (2003) Pyruvate protection against $\beta$-amyloid-induced neuronal death: role of mitochondrial redox state. J Neurosci Res 73:260-269. CrossRef Medline

Amigo I, Traba J, González-Barroso MM, Rueda CB, Fernández M, Rial E, Sánchez A, Satrústegui J, Del Arco A (2013) Glucagon regulation of oxidative phosphorylation requires an increase in matrix adenine nucleotide content through $\mathrm{Ca}^{2+}$-activation of the mitochondrial ATP-mg/pi carrier SCaMC-3. J Biol Chem 288:7791-7802. CrossRef Medline

Aprille JR (1988) Regulation of the mitochondrial adenine nucleotide pool size in liver: mechanism and metabolic role. FASEB J 2:2547-2556. Medline

Aprille JR, Rohweder-Dunn G, Brennan WA Jr, Kelley RT, Nosek MT (1987) Mitochondrial function after acute alteration of the endogenous insulinto-glucagon ratio. Biochem Biophys Res Commun 142:315-321. CrossRef Medline

Ashton AC, Ushkaryov YA (2005) Properties of synaptic vesicle pools in mature central nerve terminals. J Biol Chem 280:37278-37288. CrossRef Medline

Asimakis GK, Aprille JR (1980) In vitro alteration of the size of the liver mitochondrial adenine nucleotide pool: correlation with respiratory functions. Arch Biochem Biophys 203:307-316. CrossRef Medline

Attwell D, Laughlin SB (2001) An energy budget for signaling in the grey matter of the brain. J Cereb Blood Flow Metab 21:1133-1145. CrossRef Medline

Bak LK, Obel LF, Walls AB, Schousboe A, Faek SA, Jajo FS, Waagepetersen HS. (2012) Novel model of neuronal bioenergetics: postsynaptic utilization of glucose but not lactate correlates positively with $\mathrm{Ca}^{2+}$ signalling in cultured mouse glutamatergic neurons. ASN Neuro 4:e00083. CrossRef Medline

Balaban RS (2009) The role of $\mathrm{Ca}(2+)$ signaling in the coordination of mitochondrial ATP production with cardiac work. Biochim Biophys Acta 1787:1334-1341. CrossRef Medline

Baughman JM, Perocchi F, Girgis HS, Plovanich M, Belcher-Timme CA, Sancak Y, Bao XR, Strittmatter L, Goldberger O, Bogorad RL, Koteliansky $\mathrm{V}$, Mootha VK (2011) Integrative genomics identifies MCU as an essential component of the mitochondrial calcium uniporter. Nature 476:341345. CrossRef Medline

Brand MD, Nicholls DG (2011) Assessing mitochondrial dysfunction in cells. Biochem J 435:297-312. CrossRef Medline

Cárdenas C, Miller RA, Smith I, Bui T, Molgó J, Müller M, Vais H, Cheung KH, Yang J, Parker I, Thompson CB, Birnbaum MJ, Hallows KR, Foskett JK (2010) Essential regulation of cell bioenergetics by constitutive InsP3 receptor $\mathrm{Ca}^{2+}$ transfer to mitochondria. Cell 142:270-283. CrossRef Medline

Cerdan S, Künnecke B, Seelig J (1990) Cerebral metabolism of $\left[1,2-{ }^{13} \mathrm{C}_{2}\right]$ acetate as detected by in vivo and in vitro ${ }^{13} \mathrm{C}$ NMR. J Biol Chem 265: 12916-12926. Medline

Chouhan AK, Ivannikov MV, Lu Z, Sugimori M, Llinas RR, Macleod GT (2012) Cytosolic calcium coordinates mitochondrial energy metabolism with presynaptic activity. J Neurosci 32:1233-1243. CrossRef Medline

Courtney MJ, Lambert JJ, Nicholls DG (1990) The interactions between plasma membrane depolarization and glutamate receptor activation in the regulation of cytoplasmic free calcium in cultured cerebellar granule cells. J Neurosci 10:3873-3879. Medline

Cuezva JM, Burkett ES, Kerr DS, Rodman HM, Patel MS (1982) The new- 
born of diabetic rat: 1 . hormonal and metabolic changes in the postnatal period. Pediatr Res 16:632-637. CrossRef Medline

del Arco A, Satrústegui J (1998) Molecular cloning of Aralar, a new member of the mitochondrial carrier superfamily that binds calcium and is present in human muscle and brain. J Biol Chem 273:23327-23334. CrossRef Medline

del Arco A, Satrústegui J (2004) Identification of a novel human subfamily of mitochondrial carriers with calcium-binding domains. J Biol Chem 279:24701-24713. CrossRef Medline

De Stefani D, Raffaello A, Teardo E, Szabò I, Rizzuto R (2011) A fortykilodalton protein of the inner membrane is the mitochondrial calcium uniporter. Nature 476:336-340. CrossRef Medline

Drago I, Pizzo P, Pozzan T (2011) After a century mitochondrial in- and efflux machineries reveal themselves. EMBO J 30:4119-4125. CrossRef Medline

Fiermonte G, De Leonardis F, Todisco S, Palmieri L, Lasorsa FM, Palmieri F (2004) Identification of the mitochondrial ATP-mg/pi transporter: bacterial expression, reconstitution, functional characterization, and tissue distribution. J Biol Chem 279:30722-30730. CrossRef Medline

Gellerich FN, Gizatullina Z, Arandarcikaite O, Jerzembek D, Vielhaber S, Seppet E, Striggow F (2009) Extramitochondrial $\mathrm{Ca}^{2+}$ in the nanomolar range regulates glutamate-dependent oxidative phosphorylation on demand. PLoS One 4:e8181. CrossRef Medline

Gellerich FN, Gizatullina Z, Trumbekaite S, Korzeniewski B, Gaynutdinov T, Seppet E, Vielhaber S, Heinze HJ, Striggow F (2012) Cytosolic $\mathrm{Ca}^{2+}$ regulates the energization of isolated brain mitochondria by formation of pyruvate through the malate-aspartate shuttle. Biochem J 443:747-755. CrossRef Medline

Gellerich FN, Gizatullina Z, Gainutdinov T, Muth K, Seppet E, Orynbayeva Z, Vielhaber S (2013) The control of brain mitochondrial energization by cytosolic calcium: the mitochondrial gas pedal. IUBMB Life 65:180-190. CrossRef Medline

Glancy B, Balaban RS (2012) Role of mitochondrial $\mathrm{Ca}^{2+}$ in the regulation of cellular energetics. Biochemistry 51:2959-2973. CrossRef Medline

Grossbard L, Schimke RT (1966) Multiple hexokinases of rat tissues: purification and comparison of soluble forms. J Biol Chem 241:3546-3560. Medline

Grynkiewicz G, Poenie M, Tsien RY (1985) A new generation of $\mathrm{Ca}^{2+}$ indicators with greatly improved fluorescence properties. J Biol Chem 260: 3440-3450. Medline

Hayakawa Y, Nemoto T, Iino M, Kasai H (2005) Rapid $\mathrm{Ca}^{2+}$-dependent increase in oxygen consumption by mitochondria in single mammalian central neurons. Cell Calcium 37:359-370. CrossRef Medline

Helmchen F, Borst JG, Sakmann B (1997) Calcium dynamics associated with a single action potential in a CNS presynaptic terminal. Biophys J 72:1458-1471. CrossRef Medline

Jalil MA, Begum L, Contreras L, Pardo B, Iijima M, Li MX, Ramos M, Marmol P, Horiuchi M, Shimotsu K, Nakagawa S, Okubo A, Sameshima M, Isashiki Y, del Arco A, Kobayashi K, Satrústegui J, Saheki T (2005) Reduced $\mathrm{N}$-acetylaspartate levels in mice lacking Aralar, a brain- and muscle-type mitochondrial aspartate-glutamate carrier. J Biol Chem 280:31333-31339. CrossRef Medline

Jouaville LS, Pinton P, Bastianutto C, Rutter GA, Rizzuto R (1999) Regulation of mitochondrial ATP synthesis by calcium: evidence for a long-term metabolic priming. Proc Natl Acad Sci U S A 96:13807-13812. CrossRef Medline

Kelly JF, Furukawa K, Barger SW, Rengen MR, Mark RJ, Blanc EM, Roth GS, Mattson MP (1996) Amyloid beta-peptide disrupts carbachol-induced muscarinic cholinergic signal transduction in cortical neurons. Proc Natl Acad Sci U S A 93:6753-6758. CrossRef Medline

Kipanyula MJ, Contreras L, Zampese E, Lazzari C, Wong AK, Pizzo P, Fasolato C, Pozzan T (2012) $\mathrm{Ca}^{2+}$ dysregulation in neurons from transgenic mice expressing mutant presenilin 2. Aging Cell 11:885-893. CrossRef Medline

Lewis LD, Ljunggren B, Norberg K, Siesj ö BK (1974) Changes in carbohydrate substrates, amino acids and ammona in the brain during insulininduced hypoglycemia. J Neurochem 23:659-671. CrossRef Medline

Litjens T, Harland ML, Roberts ML, Barritt GJ, Rychkov GY (2004) Fast$\mathrm{Ca}^{2+}$-dependent inactivation of the store-operated $\mathrm{Ca}^{2+}$ current (ISOC) in liver cells: a role for calmodulin. J Physiol 558:85-97. CrossRef Medline

Lucas-Meunier E, Fossier P, Baux G, Amar M (2003) Cholinergic modulation of the cortical neuronal network. Pflugers Arch 446:17-29. Medline
Mallilankaraman K, Cárdenas C, Doonan PJ, Chandramoorthy HC, Irrinki KM, Golenár T, Csordás G, Madireddi P, Yang J, Müller M, Miller R, Kolesar JE, Molgó J, Kaufman B, Hajnóczky G, Foskett JK, Madesh M (2012a) MCUR1 is an essential component of mitochondrial $\mathrm{Ca}^{2+}$ uptake that regulates cellular metabolism. Nat Cell Biol 14:1336-1343. CrossRef Medline

Mallilankaraman K, Doonan P, Cárdenas C, Chandramoorthy HC, Müller M, Miller R, Hoffman NE, Gandhirajan RK, Molgó J, Birnbaum MJ, Rothberg BS, Mak DO, Foskett JK, Madesh M (2012b) MICU1 is an essential gatekeeper for MCU-mediated mitochondrial $\mathrm{Ca}(2+)$ uptake that regulates cell survival. Cell 151:630-644. CrossRef Medline

Martinez-Serrano A, Blanco P, Satrústegui J (1992) Calcium binding to the cytosol and calcium extrusion mechanisms in intact synaptosomes and their alterations with aging. J Biol Chem 267:4672-4679. Medline

Mathiesen C, Caesar K, Thomsen K, Hoogland TM, Witgen BM, Brazhe A, Lauritzen M (2011) Activity-dependent increase in local oxygen consumption correlate with postsynaptic currents in the mouse cerebellum in vivo. J Neurosci 31:18327-18337. CrossRef Medline

McCormack JG, Halestrap AP, Denton RM (1990) Role of calcium ions in regulation of mammalian intramitochondrial metabolism. Physiol Rev 70:391-425. Medline

Mitchell P, Moyle J (1969) Estimation of membrane potential and pH difference across the cristae membrane of rat liver mitochondria. Eur J Biochem 7:471-484. Medline

Nakano M, Imamura H, Nagai T, Noji H (2011) $\mathrm{Ca}^{2+}$ regulation of mitochondrial ATP synthesis visualized at the single cell level. ACS Chem Biol 15:709-715. CrossRef Medline

Nicholls DG (2005) Mitochondria and calcium signaling. Cell Calcium 38: 311-317. CrossRef Medline

Palmieri L, Pardo B, Lasorsa FM, del Arco A, Kobayashi K, Iijima M, Runswick MJ, Walker JE, Saheki T, Satrústegui J, Palmieri F (2001) Citrin and aralarl are $\mathrm{Ca}^{2+}$-stimulated aspartate/glutamate transporters in mitochondria. EMBO J 20:5060-5069. CrossRef Medline

Pardo B, Contreras L, Serrano A, Ramos M, Kobayashi K, Iijima M, Saheki T, Satrústegui J (2006) Essential role of Aralar in the transduction of small $\mathrm{Ca}^{2+}$ signals to neuronal mitochondria. J Biol Chem 281:1039-1047. CrossRef Medline

Pardo B, Rodrigues TB, Contreras L, Garzón M, Llorente-Folch I, Kobayashi K, Saheki T, Cerdan S, Satrústegui J (2011) Brain glutamine synthesis requires neuronal-born aspartate as amino donor for glial glutamate formation. J Cereb Blood Flow Metab 31:90-101. CrossRef Medline

Putney JW (2009) Capacitative calcium entry: from concept to molecules. Immunol Rev 231:10-22. CrossRef Medline

Qian W, Van Houten B (2010) Alterations in bioenergetics due to changes in mitochondrial DNA copy number. Methods 51:452-457. CrossRef Medline

Ramos M, del Arco A, Pardo B, Martínez-Serrano A, Martínez-Morales JR, Kobayashi K, Yasuda T, Bogónez E, Bovolenta P, Saheki T, Satrústegui J (2003) Developmental changes in the $\mathrm{Ca}^{2+}$-regulated mitochondrial aspartate-glutamate carrier aralar1 in brain and prominent expression in the spinal cord. Brain Res Dev Brain Res 143:33-46. CrossRef Medline

Rego AC, Ward MW, Nicholls DG (2001) Mitochondria control AMPA/ kainate receptor-induced cytoplasmic calcium deregulation in rat cerebellar granule cells. J Neurosci 21:1893-1901. Medline

Rizzuto R, De Stefani D, Raffaello A, Mammucari C (2012) Mitochondria as sensors and regulators of calcium signalling. Nat Rev Mol Cell Biol 13: 566-578. CrossRef Medline

Rose CR, Ransom BR (1997) Regulation of intracellular sodium in cultured rat hippocampal neurones. J Physiol 499:573-587. Medline

Ruiz F, Álvarez G, Pereira R, Hernández H, Villalba M, Cruz F, Cerdán S, Bogónez E, Satrústegui J (1998) Protection by piruvate and malate against glutamate-mediated excitotoxicity. Neuroreport 9:1277-1282. Medline

Sánchez-Cenizo L, Formentini L, Aldea M, Ortega AD, García-Huerta $\mathrm{P}$, Sánchez-Aragó M, Cuezva JM (2010) Up-regulaton of the ATPase inhibitory factor 1 (IF1) of the mitochondrial $\mathrm{H}+$-ATP synthase in human tumors mediates the metabolis shift of cancer cells to a Warburg phenotype. J Biol Chem 285:25308-25313. CrossRef Medline

Satrústegui J, Pardo B, del Arco A (2007) Mitochondrial transporters as novel targets for intracellular calcium signaling. Physiol Rev 87:29-67. CrossRef Medline 
Stacpoole PW (2012) The pyruvate dehydrogenase complex as a therapeutic target for age-related diseases. Aging Cell 11:371-377. CrossRef Medline

Strichartz G, Rando T, Wang GK (1987) An integrated view of the molecular toxinology of sodium channel gating in excitable cells. Annu Rev Neurosci 10:237-267. CrossRef Medline

Traba J, del Arco A, Duchen MR, Szabadkai G, Satrústegui J (2012) SCaMC-1 promotes cancer cell survival by desensitizing mitochondrial permeability transition via ATP/ADP-mediated matrix $\mathrm{Ca}(2+)$ buffering. Cell Death Differ 19:650-660. CrossRef Medline

Zhao Y, Araki S, Wu J, Teramoto T, Chang YF, Nakano M, Abdelfattah AS, Fujiwara M, Ishihara T, Nagai T, Campbell RE (2011) An expanded palette of genetically encoded $\mathrm{Ca}^{2+}$ indicators. Science 333:1888-1891. CrossRef Medline 